NBER WORKING PAPER SERIES

\title{
THE ANTEBELLUM TRANSPORTATION \\ REVOLUTION AND FACTOR-PRICE CONVERGENCE
}

Matthew J. Slaughter

Working Paper 5303

\author{
NATIONAL BUREAU OF ECONOMIC RESEARCH \\ 1050 Massachusetts Avenue \\ Cambridge, MA 02138 \\ October 1995
}

Some of this work was supported by a National Science Foundation Graduate Fellowship and by an MIT Industrial Performance Center Dissertation Fellowship. For helpful comments I thank Paul Krugman, Lael Brainard, Peter Temin, Robert Margo, Jeremy Atack, Larry Katz, Andrew Bernard, Gordon Hanson, Mark Hooker, and participants at the 1995 NBER Development of the American Economy Summer Institute. John Hiler provided outstanding research assistance. This paper is part of NBER's research program in International Trade and Investment. Any opinions expressed are those of the author and not those of the National Bureau of Economic Research.

() 1995 by Matthew J. Slaughter. All rights reserved. Short sections of text, not to exceed two paragraphs, may be quoted without explicit permission provided that full credit, including (-) notice, is given to the source. 


\title{
THE ANTEBELLUM TRANSPORTATION \\ REVOLUTION AND FACTOR-PRICE \\ CONVERGENCE
}

\begin{abstract}
In antebellum America an extensive network of canals and railroads was constructed which slashed transportation costs across regions. This "transportation revolution" presents an interesting case study of the factor-price convergence (FPC) theorem. In this paper I look for integration of regional labor markets driven by FPC by studying the extent to which commodity prices and factor prices converged across regions between 1820 and 1860. My primary result is that I find very little evidence of antebellum FPC across regions. I do find that commodity prices equalized quite markedly. But I also find that nominal labor prices equalized very little, if at all. Given this result, I go on to discuss two aspects of the antebellum economy which very likely helped prevent FPC: differences across regions in endowments and technology. This finding underscores that the FPC theorem does not have unambiguous empirical predictions. How commodity prices feed into factor prices depends crucially on parameters such as endowments and technology.
\end{abstract}

Matthew J. Slaughter

Department of Economics

Dartmouth College

Hanover, NH 03755

and NBER 


\section{Introduction}

The geographic integration of regional labor markets in the United States has received a good deal of attention from economic historians. Almost all work on 19th-century America has told a supply-side story in which labor moves across regions to arbitrage real-wage differentials. Thus, for example, antebellum westward migration is explained by the lure of higher real wages in the Midwest. Studies of integration via migration have yielded valuable insights into the formation of one national labor market.

In this paper I analyze a second possible cause of antebellum labor-market integration: the "transportation revolution" which sharply cut interregional transportation costs by building canals and railroads. In contrast with migration, this is a demand-side story in which the causal link between transportation and the labor market is the factor-price-convergence (FPC) theorem from international trade. ${ }^{1}$ The basic idea is that falling trade barriers tend to equalize commodity prices across regions; in turn, under certain conditions this commodity-price convergence tends to equalize nominal factor prices as well. The mechanism by which this happens is labor demand. As commodity-price changes induce producers to shift resources across industries, demand shifts for factors of production such as labor. Thus, mobility of goods can substitute for mobility of factors to equalize factor prices even when factors are completely immobile. To my knowledge, no study of the 19th-century American labor market has analyzed the relevance of FPC. People have looked at commodity markets and labor markets, but no one has linked the former to the latter.

To look for antebellum integration of regional labor markets driven by FPC, I study the extent to which commodity prices and factor prices converged across regions between 1820 and 1860 . The commodity-price data come from Cole (1938), and the wage data come from Margo and Villaflor (1987) and Goldin and Margo (1992).

My primary result is that I find very little evidence of antebellum FPC across regions. I do find that commodity prices equalized quite markedly. For a group of ten major goods, the ratios of wholesale prices across regions converged towards one at an average rate of about $1 \%$ per year.

\footnotetext{
${ }^{1}$ As will be discussed, this terminology comes from Leamer (1995). The original theory is in Heckscher and Ohlin (1991).
} 
Similarly, the differences between wholesale prices across regions converged towards zero at an average rate of about $4 \%$ per year. But I also find that nominal labor prices equalized very little, if at all. For a sample of three labor types across four regions, both the ratios of and the differences between nominal wages across regions showed no broad pattern of convergence--indeed, several of the wage series diverged. Canals and railroads did integrate product markets quite strongly, but this in turn did not integrate labor markets through FPC.

Given this result, I analyze how two aspects of the antebellum economy very likely helped prevent FPC. First, endowments may have been sufficiently dissimilar across regions that each produced a different set of goods. When a region does not produce all goods, its factor demands need not adjust to commodity-price convergence in a way which converges factor prices as well. Second, there is evidence of substantial interregional differences in antebellum technology. When regions use different technologies, factor demands differ and need not converge factor prices. Thus, the combination of endowment and technology differences probably prevented FPC. This finding underscores that the FPC theorem does not have unambiguous empirical predictions. How commodity prices feed into factor prices depends crucially on parameters such as endowments and technology.

This paper has five additional sections. Next it explains the FPC theorem and surveys the literature on 19th century labor-market integration. Then it documents the fall in transportation costs and analyzes the extent of commodity-price equalization. It then analyzes the extent of factorprice equalization. After this it discusses how differences in regional endowments and technology seem to have prevented labor-market integration through FPC. Finally it concludes and discusses possible research ideas.

\section{Previous Studies of Labor-Market Integration and FPC}

\section{The FPC Theorem}

The FPC Theorem is a corollary of the factor-price equalization (FPE) theorem. The difference between the two is that FPE refers to an outcome but FPC refers to a process. 
The FPE theorem is often defined as the set of endowment points among regions for which commodity trade has equalized not only goods prices but also factor prices as well. Equal goods prices are linked to equal factor prices through factor demands: as goods-price changes induce resource reallocation across industries, demand--and thus prices--for factors changes as well. Under certain assumptions about technology and the mix of goods produced, equal commodity prices result in equal factor prices as well. Moreover, at these factor prices demand may be infinitely elastic. In this case vectors of commodity prices map one-for-one into vectors of factor prices and factor supplies are irrelevant.

The appropriate empirical test for FPE is simply whether factor prices are equal across regions at some point in time. Not surprisingly, FPE has repeatedly been found to be a spectacular failure. In light of this, Caves (1960) and others have wondered "why the factor-price equalization theorem has attracted so much attention ... In light of the data, the whole discussion [of FPE] is, for better or for worse, a supreme example of non-operational theorizing."

In Slaughter (1994) I argue that looking for equal factor prices is the wrong way to go about things. In most models FPE requires several stringent assumptions which almost certainly do not all hold in reality. For example, in Samuelson (1949) eight stringent assumptions must jointly hold--including zero trade barriers, identical linear homogeneous technology and preferences across regions, and all regions producing all products. Thus, FPE fails empirically because its necessary assumptions fail empirically. Thinking about FPE as both an equilibrium outcome and a set of stringent assumptions motivates an alternative empirical approach. One can look for a tendency towards FPE triggered by a tendency towards realizing its stringent assumptions. Here the focus is on the interaction over time between trends in the assumptions needed to equalize prices and trends in the prices themselves. Not "Are factor prices equal?", but rather "Are factor prices equalizing as trade becomes freer?"

This is what Leamer $(1995, \mathrm{p} .7)$ calls the FPC theorem:

When two countries eliminate their mutual trade barriers, product-price equalization eliminates factor-price differences ... This [FPC] theorem is different [from the FPE theorem] in subtle but important ways. First, by its lack of explicitness, it challenges us to find combinations of assumptions regarding factor-supply differences, technological 
differences, and numbers of factors and goods for which economic integration reduces international factor-price differences. Second, it makes explicit reference to the 'signal' by which the effects of economic integration are transmitted among countries. This signal is the change in product prices resulting from integration.

It is important to point out that like FPE, FPC operates through factor demands. As product prices converge across regions, within regions producers' demands for factors shift in response. The Stolper-Samuelson theorem describes how the link from product-price changes to factor-price changes depends on the factor intensity of production: a rise in the price of a good tends to raise (lower) the return to factors used intensively (unintensively) in its production. This is because as resources shift into that good's industry, demand for its intensive factors rises.

A good example of testing FPC in this manner is O'Rourke and Williamson (1994). They document how lower freight charges helped lower the wage-rental ratio in the United States and raise it in Europe. ${ }^{2}$ My approach is similar to this. I look for convergence of commodity prices induced by canals and railroads, and then I look for convergence of factor prices. ${ }^{3}$

\section{Previous Studies of Labor-Market Integration}

In recent years several papers have documented aspects of antebellum labor-market integration. Rothenberg (1988) finds that a rural labor market emerged in Massachusetts by about 1800. Margo and Villaflor (1987) and Margo (1992) find that interregional real-wage differentials were slowly shrinking. Adams (1992) finds that real-wage movements in West Virginia broadly matched those in Delaware and Maryland. And Sokoloff and Villaflor (1992) find rather small geographic variation in Northeast nominal wages by 1860 .

\footnotetext{
2From 1870 to 1913, in labor-scarce, land-rich United States the wage-rental ratio fell while in labor-rich, land-scarce Europe the wage-rental ratio rose. One potential cause of this convergence was FPC triggered by falling costs of ocean freight (other causes include labor migration from Europe, more rapid capital accumulation in the United $S$ tates, and technological change). Between 1870 and 1910 Atlantic freight rates fell by somewhere between 41 and 53 percent: in turn, price differentials for several commodities narrowed from $60-90 \%$ to only $10-20 \%$. To determine the relative contribution of FPE and other causes, the authors run counterfactual CGE simulations in which the transportation shock is introduced while holding constant all other causes. They find that all else equal, lower transportation costs and their resultant equalizing commodity prices explain two-thirds of the wage-rental convergence between England and the United States from 1870 to 1895 . One advantage of my study is that it looks at regions within a common-currency area. This avoids the question of what exchange rates to use to convert factor prices into a common currency.

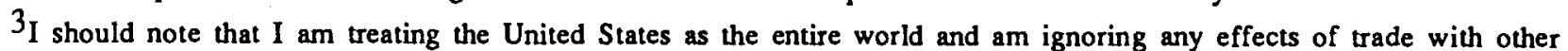
countries. This is not too bad an assumption: between 1834 and 1858 , exports accounted for only about $6 \%$ of G.D.P. Regardless of the effects of international trade, however, the effects of interregional trade on regional labor markets still matter.
} 
People have looked at postbellum labor markets as well. Rosenbloom (1990) finds persistent real-wage differentials both within and between regions, while Rosenbloom (1991) measures integration in terms of the elasticity of local labor supply for various occupations in 1890. And Hatton and Williamson (1991b) find that in Michigan in 1890 jobs with higher seasonal-layoff risk paid higher wages, while Hatton and Williamson (1991c) find that the 50\% nominal-wage gap between rural and city wages in 1890 s Michigan shrinks to a $10 \%$ real-compensation gap after adjusting for perquisites and costs of living.

My work differs from these studies in two important ways. First is scope: I look for labormarket integration exclusively across regions, not within them. I do this because the data on commodity prices indicate strong commodity-price convergence across regions.

Second is methodology: I look for labor-market integration driven by FPC, not migration. All the studies just cited speak about labor-market integration only in terms of migration. ${ }^{4}$ In fact, Rosenbloom (1990, p.88) argues that FPC cannot cause integration: "Two problems make it difficult to infer the extent of labor market integration from the behavior of wages ... Second, the integration of markets for finished products and/or other factors of production will tend to equalize wages even if labor is completely immobile, creating the appearance of labor market integration even where it does not exist." For Rosenbloom and others, labor-market integration apparently must involve labor mobility. I argue, however, that a broader definition which acknowledges FPC is more appropriate. If labor-market integration is defined as wage equalization arising from any source, then FPC seems to be as legitimate a cause as migration is. ${ }^{5}$

\footnotetext{
${ }^{4}$ The one exception is Sokoloff and Villaflor (pp. 35-37), who argue that labor-market integration is driven "both through enhanced labor mobility and adjustments by employers to changes in their product markets. Wage rates in different areas were driven toward convergence by competition between producers as the radiation of ... [transport] promoted the extension of markets throughout the Northeast." But they do not look beyond the Northeast, they do not explicitly refer to FPC, and they do not analyze commodity and factor prices together.

$5 \mathrm{My}$ focus on integration via FPC does not imply that integration via migration did not matter. Clearly, in a world with (somewhat) mobile goods and factors, both varieties of integration can operate simultaneously.
} 


\section{Antebellum Commodity Prices}

\section{Transportation Costs}

Table 1 summarizes the growth in transportation mileage between 1820 and 1860 . The "transportation revolution" is often broken into two major stages. The first stage was the construction of canals. In 1816 the country had only 100 miles of operating canals, and only three canals were longer than two miles. The construction of the Erie Canal from 1818 to 1825 changed all this. "The success of the Erie Canal provided the spark which set off a nation-wide craze for canal building. With the need for improved transportation so great and the financial and economic benefits to be secured from artificial waterways now apparently assured, a veritable canal-building fury gripped the country" (Taylor, 1951, p.34). This stage also involved further spread of steamboats. First successfully used by Robert Fulton on the Hudson River in 1807, steamboats allowed goods to be shipped on waterways (natural and canals) upstream as well as downstream both in greater volumes and in shorter times. The second stage was the construction of railroads. The first successful experiments of railroads were conducted in England in the 1820's, and thereafter railroads expanded in the United States as technical difficulties with track and steam engines were worked out. By 1850 most major problems had been solved, and in the 1850's America nearly quadrupled its track mileage.

Through continual advances in technology and competition among producers, this revolution slashed transportation costs throughout the country. A number authors have assembled a lot of evidence here. Taylor finds that the fall in costs was on the order of $95 \%$ for some goods. Berry documents dozens of interesting cases. For example, in New York over the 1850's alone, the cost for a ton-mile of first-class railroad freight fell from 9.04 cents in 1850 to 2.2 cents in 1860 . Similarly, between Baltimore and Cincinnati the rate for one hundred pounds of "direct rates" fell from $\$ 2.50$ in 1821 to $\$ 1.05$ in 1860 . And between Louisville and New Orleans, rates per pound fell from four cents in 1816 to 0.31 cents in 1860 . Berry also measures falling costs in terms of time. In 1817 it took 52 days to ship "a load of freight" from Cincinnati to New York City via wagons and riverboats. In 1852 it took only six days to ship the same freight all via the Erie 
Railroad and connecting lines. Finally, Williamson and Lindert (1980) measure falling costs in terms of productivity gains: they estimate that overall transportation productivity rose $4.68 \%$ per year between 1815 and 1859 .

Overall, many products and locations experienced substantial cost declines. I do not try to estimate an overall rate of decline across all products and locations. Undoubtedly, transportation costs for all the product-location pairs in my data set declined at different rates. But because the focus of this paper is general equilibrium, I usually abstract from these differences to emphasize trends common to all the data.

\section{Commodity Prices: Data}

As transportation costs fell, the volume of internal trade on all forms of transport expanded dramatically. For example, the total volume of produce shipped from the Midwest to the Northeast increased from 54,219 tons in 1836 to 2,393,171 tons in 1860 (Fishlow, 1965). At the same time patterns of trade shifted as well. For example, before canals and railroads a large amount of eastwest trade traveled via New Orleans because the cheapest route used the Mississippi River and the Atlantic Ocean. As canals and railroads superseded this roundabout east-west trade, the share of total western food exports shipped via New Orleans fell from $49 \%$ in 1839 to $17 \%$ in 1860 (Fishlow 1965).

In light of this expansion in interregional trade, the logical question is whether commodity prices across regions equalized as well. A few people have found some evidence of this. Cole (1938) constructs aggregate price series for six cities and finds the same broad pattern over time across cities. Using Cole's data, Berry (1943) finds that the absolute price differences between Cincinnati and other cities averaged over 5-year periods for a few commodities such as coffee and sugar were shrinking from 1816 to 1820 . Similarly, Adams (1992) finds that goods prices in West Virginia, Philadelphia, and Maryland were generally converging after 1790.

My results corroborate these findings, but I try to improve on them in two important ways. First, I look at a broad set of goods: both manufactures and foodstuffs, most of which were major components of typical households' consumption baskets. Second, I estimate rates of convergence 
to establish a benchmark for judging wage convergence. These rates are my measure of the general-equilibrium trend common to all products (and similarly for the rates for wages).

I use Cole's data, which are monthly wholesale prices collected from newspapers and other primary sources for dozens of commodities between 1700 and 1861 at six cities: Boston, New York, Philadelphia, Charleston, New Orleans, and Cincinnati. For measuring price convergence, wholesale prices are preferable to retail prices because the latter include the non-traded costs of retail distribution and final sale.

Using Cole's wholesale prices implies at least two important assumptions. First, it is assumed that transportation advances were affecting the six cities. This was likely the case for most products and cities. Steamboats probably benefited all six cities because each sits on a major river and/or body of water. Canals helped too. For example, the Erie canal linked New York and Philadelphia to Cincinnati and the Midwest. And railroads forged even more links: by 1853 four trunk lines connected the Northeast and the Midwest.

Second, it is assumed that urban prices reflect overall regional prices. In levels this may not have been the case: rural prices probably exceeded urban prices because of additional transportation costs, among other reasons. But this rural-urban price gap should have been decreasing as canals and railroads integrated within regions as well. Indeed, to the extent that transportation innovations benefited hinterlands more than cities, Cole's data understate regional price changes. ${ }^{6}$

To measure goods-price convergence across regions I needed to identify regions, times, and goods. First, there are four regions: Midwest, with Cincinnati; Northeast, with New York and Philadelphia (Boston prices were too sporadic to use); South Atlantic, with Charleston; and South

\footnotetext{
${ }^{6}$ Because Cole's six cities abut water, before the transportation revolution they were probably more tightly integrated than were hinterlands. Thanks to this initial backwardness, if transportation innovations reached rural areas then those areas should have benefited more than cities. In fach, canals and railroads did have this reach. Taylor (1951, p 37) points out that post-Erie Canal two of the three major canal-building waves were intraregional, not interregional: "(1) those designed to improve transportation between the upcountry and tidewater in states bordering on the Atlantic from Maine to Virginia; (2) those, like the Erie, designed to link the Atlantic states with the Ohio River Valley; and (3) those in the West which were planned to connect the Ohio-Mississippi system with the Great Lakes. In New York, Pennsylvania, and Ohio the main line canals were supplemented by an extensive system of branches or feeders." For railroads, several people have noted how much of their spread, especially in the 1850 's, extended branch lines off the main east-west trunk lines. For example, Berry (1951, p 83) comments that for Ohio, "the state was honeycombed with railways between 1845 and $1860 \ldots$ with the result that more and more of the interior was opened up." So because canals and railroads did reach far beyond cities, Cole's data probably understate regional price changes.
} 
Central, with New Orleans. These four regions are the regions by which the wage data are reported. Second, I dated the transportation revolution both from 1820 to 1860 and from 1825 to 1860. The catalyzing Erie Canal was started in 1818 but not completed until 1825 , and I end in 1860 before the Civil War starts. The basic results for both prices and wages do not depend in any way on the endpoints covered. Third, I chose commodities which met three criteria. They needed to be important--i.e., to account for a large share of household purchases; they needed continuous coverage from 1860 back to 1820 ; and they needed to be defined consistently over time and across regions to ensure comparability. ${ }^{7}$

Together, these criteria left me with the ten goods listed in table 2 . The coverage seems balanced across regions and commodity types. Five commodities have prices in only two cities, but the other five have prices in three cities. These latter five allow some check against the results being driven by interactions between two cities that are unrepresentative of the country overall. Five commodities are manufactures (coal, cotton, iron, molasses, and nails), the other five foodstuffs (butter, coffee, flour, pork, and sugar). And seven commodities (five foodstuffs plus coal and cotton) were major components of the typical household consumption basket. According to the expenditure shares given in Goldin and Margo (1992) and listed in column 2 of Table 2, the seven products together accounted for about $77 \%$ of total non-housing expenditures. 8

\section{Commodity Prices: Methodology}

In theory there are at least two ways to model transportation costs and their effect on prices. One is to assume that costs are ad valorem. In this case the relationship between prices in regions $A$ and $B$ is given by

$$
\text { (1) } \quad \mathrm{P}_{\mathrm{B}}=\left(1+\mathrm{tc} \mathrm{c}_{\mathrm{av}}\right) \mathrm{P}_{\mathrm{A}} \text {, }
$$

where $\mathrm{tc}_{\mathrm{av}} \equiv$ the percentage ad valorem transportation cost with $\mathrm{tc}_{\mathrm{av}}>0$ and pricès are assumed to be lower in region $A$. Canals and railroads lower $t c_{a v}$, and as it approaches zero $\frac{\mathrm{P}_{\mathrm{B}}}{\mathrm{P}_{\mathrm{A}}}$ approaches

\footnotetext{
7 For example, in 1844 the records for candle prices in Philadelphia switch from tallow-mould candles to sperm candles. Because I do not know the quality difference between the two varieties, I could not track candles. This is not to say that quality did not change over time for goods defined consistently. However, I assume that these changes occurred in all locations.

${ }^{8}$ For each commodity $I$ averaged its budget share over all regions in which it was listed. I then summed the seven average shares to get to $77 \%$.
} 
one. Thus ad valorem transportation costs drive a relative wedge between prices, and convergence implies that the relative-price ratio $\frac{\mathrm{P}_{\mathrm{B}}}{\mathrm{P}_{\mathrm{A}}}$ approaches one (and similarly for factor prices).

The second possible way to model transportation costs is to assume they are specific. In this case the relationship between $P_{A}$ and $P_{B}$ is given by

$$
\mathrm{P}_{\mathrm{B}}=\mathrm{P}_{\mathrm{A}}+\mathrm{tc} \mathrm{c}_{\mathrm{s}} \text {, }
$$

where $t c_{s} \equiv$ the dollar specific transportation cost with $t c_{s}>0$ and prices are again assumed lower in region $A$. Canals and railroads lower $t c_{s}$, and as it approaches zero $\left(\mathrm{P}_{\mathrm{B}}-\mathrm{P}_{\mathrm{A}}\right)$ approaches zero. Thus specific transportation costs drive an absolute wedge between prices, and convergence implies that the absolute-price difference $\left(\mathrm{P}_{\mathrm{B}}-\mathrm{P}_{\mathrm{A}}\right)$ approaches zero (and similarly for factor prices).

The empirical problem is that there is no necessary relationship between these absolute and relative price wedges. One shrinking need not imply that the other is shrinking. 9 The question then becomes whether one thinks actual advances in transportation eliminate relative or absolute differences. There does not seem to be consensus on this in the literature. Trade economists usually model ad valorem costs, but historians looking at 19th-century integration go both ways: Margo (1992), Hatton and Williamson (1991a), and Adams (1992) look for convergence in relative real wages but Bodenhorn and Rockoff (1992), James (1976), and others look for convergence in absolute interest rates.

Given this lack of consensus, I model transportation costs both ways and thus look for convergence across regions for goods and factors both in relative-price ratios and in absolute-price differences. The basic results are the same either way.

To test both models, for each commodity in each city I constructed an average annual price equal to the arithmetic average each year's monthly prices. 10 For ad valorem costs, I then constructed 15 price ratios which are listed in column 3 of table 2 . Five commodities have just one

\footnotetext{
${ }^{9}$ For example, suppose that in period one $P_{A}=5$ and $P_{B}=10$ while in period two $P_{A}=1$ and $P_{B}=3$. Between the two periods absolute prices converge but relative prices diverge. Flip the time periods around and the reverse occurs: relative convergence but absolute divergence.

${ }^{10}$ The results do not appear to be sensitive to this averaging. To check this, for flour I also constructed a second price series of just January prices and a third of just July prices. Trends in these two series tracked very closely the trend in the annual-average series.
} 
ratio, but five have two ratios thanks to coverage in three cities rather than just two. The ratios are constructed to be initially greater than one (i.e., of the form $\frac{\mathrm{P}_{\mathrm{B}}}{\mathrm{P}_{\mathrm{A}}}$ ) so that convergence over time manifests itself in ratios declining towards one. Similarly, for specific costs I constructed 15 price differences listed in column 3 of table 3 . These are constructed to be initially greater than zero (i.e., of the form $\left(\mathrm{P}_{\mathrm{B}}-\mathrm{P}_{\mathrm{A}}\right)$ ). Most of the price levels seem consistent with the predictions of endowment-based comparative advantage. Agriculture prices were lower in the land-abundant Midwest or in the warmth-abundant South, and manufacturing prices were lower in the capitalabundant Northeast.

Results for Price Ratios

I assume that each ratio evolves according to

$$
\left(\frac{P_{B}}{P_{A}}\right) \text { it }=A * \exp \left(\beta t \varepsilon_{i t}\right),
$$

where $i$ indexes the commodity, $t$ indexes time, $A$ is the initial ratio at time $t=0, \beta$ is the exponential rate of growth of the series, and $\varepsilon_{i t}$ is the i.i.d. error term that explains noise in the actual ratio around its assumed trend. An exponential time trend was chosen over a linear one because an exponential trend converges asymptotically. If the series converges $\beta<0$; if it diverges $\beta>0$. Taking the log of both sides gives the following log-linear regression specification:

$$
\ln \left(\frac{\mathrm{P}_{\mathrm{B}}}{\mathrm{P}_{\mathrm{A}}}\right)_{i \mathrm{t}}=\alpha_{\mathrm{i}}+\beta \mathrm{t}+\varepsilon_{\mathrm{it}} \text {. }
$$

For each of the 15 price-ratio series I ran equation (4) using OLS to estimate its $\beta$. Each series I ran twice, once starting with 1820 and once with 1825: the results were virtually identical either way. I also pooled the series in various ways to form panels for which $\mathrm{T}$ estimated one overall $\beta$ using the fixed-effects technique. Here I ran four specifications: all 15 ratios and then just 10 such that each commodity had only one ratio, each starting in 1820 and then 1825 .

Columns 4 through 6 of table 2 report the results. For each individual series the 1825 results only are listed. ${ }^{11}$ Also, the top halves of figures 1 and 2 plot the results for foodstuffs and manufactures, respectively. Each graph plots both actual and estimated price ratios against time.

\footnotetext{
11 For nine of the fifteen price-ratio series, these results actually understate the rate of convergence compared with the specifications which start in 1820 .
} 
The basic result is strong convergence towards one in every commodity ratio measured. 13 ratios converge at a rate significant at the 0.5 percent level and the other two at the 1 percent level. The estimated rates range from -0.0037 for coffee to -0.0203 for flour. ${ }^{12}$ When $I$ assume the same underlying process for all products and pool them, the estimated rate is approximately -0.01 (significant at the 0.5 percent level) for all four specifications.

Thus, taking all commodities together, price ratios in the antebellum period converged towards one at a rate of approximately $1 \%$ per year. This result can be interpreted in at least a couple ways. First, it means that a price ratio in 1860 had fallen to about 68 percent of its 1825 level (exp($0.01 * 35) \approx 0.68$ ). So an initial ratio of about 1.46 fell to 1.00 : an initial absolute-price gap of $46 \%$ disappeared completely. Similarly, an initial ratio of 2.00 fell to about 1.37: an initial absoluteprice gap of $100 \%$ fell to $37 \%$. Second, it means that the half-life of convergence for price ratios (i.e., the amount of time needed for a ratio to halve) was approximately 69 years.

Results for Price Differences

I assume that each price difference evolves according to

$$
\left(\mathrm{P}_{\mathrm{B}}-\mathrm{P}_{\mathrm{A}}\right) \mathrm{it}=\mathrm{A} * \exp \left(\beta \mathrm{t} \varepsilon_{\mathrm{it}}\right),
$$

where $i$ indexes the commodity, $t$ indexes time, $A$ is the initial level at time $t=0, \beta$ is the exponential rate of growth of the series, and $\varepsilon_{i t}$ is the i.i.d. error term that explains noise in the actual ratio around its assumed trend. Again, an exponential time trend was chosen over a linear one. If the series converges $\beta<0$; if it diverges $\beta>0$. Taking the $\log$ of both sides gives the following log-linear regression specification:

$$
\ln \left(\mathrm{P}_{\mathrm{B}}-\mathrm{P}_{\mathrm{A}}\right) \mathrm{it}=\alpha_{\mathrm{i}}+\beta \mathrm{t}+\varepsilon_{\mathrm{it}} .
$$

For each of the 15 price-difference series I ran equation (6) using OLS to estimate its $\beta$. Each series I ran twice, once starting with 1820 and once with 1825 : the results were virtually identical either way. I also pooled the series in various. ways to form panels for which I estimated one

\footnotetext{
12 The two nail-price series are the only two whose ratio actually falls below one for extended periods--both range between 0.9 and one in the last 10 to 20 years. This may have been because local demand for nails in the Midwest was sufficiently strong that it acquired comparative advantage in them from the Northeast.
} 
overall $\beta$ using the fixed-effects technique. Here I ran four specifications: all 15 series and then just 10 such that each commodity had only one series, each starting in 1820 and then 1825 .

Columns 4 through 6 of table 3 report the results. For each individual series the 1825 results only are listed. ${ }^{13}$ Also, the bottom halves of figures 1 and 2 plot the results for foodstuffs and manufactures, respectively. Each graph plots both actual and estimated price differences against time.

As before, the basic result here is strong convergence. 12 differences converge towards zero at a rate significant at the 0.5 percent level, one at the 5 percent level, and two at rates not significantly different from zero. The estimated rates range from -0.0154 for nails to -0.0950 for cotton. ${ }^{14}$ In several cases, absolute price differentials across regions started out at $30 \%$ to well over $100 \%$ and shrank to under $10 \%$. When I assume the same underlying process for all products and pool them, the estimated convergence rate is approximately -0.04 (significant at the 0.5 percent level) for all four specifications.

Thus, taking all commodities together, price differences in the antebellum period converged towards zero at a rate of approximately $4 \%$ per year. This result can be interpreted in at least a couple ways. First, it means that a price difference in 1860 had fallen to about 25 percent of its 1825 level $(\exp (-0.04 * 35) \approx 0.25)$. Second, it means that the half-life of convergence for price differences was approximately 17 years.

Overall, significant commodity-price equalization was occurring in the antebellum years. Two additional points about prices are worth making. First, although it seems reasonable to attribute a large share of the price convergence to the transportation revolution, other.factors may have mattered as well. For example, technological progress in industries may have lowered price levels. Consider iron and nails. Despite rising demand for them, their prices were falling continually in Cincinnati, New York, and Philadelphia. Technology very likely played a role here. In 1840 iron producers developed the ability to fuel their blast furnaces with anthracite and bituminous coal

\footnotetext{
13 For nine of the fifteen price-ratio series, these results actually understate the rate of convergence compared with the specifications which start in 1820 .

${ }^{14}$ The two nail-price series are the only two whose difference falls below zero for extended periods.
} 
instead of charcoal. Most observers contend that this advance lowered the price of iron. ${ }^{15}$ If this progress occurred at different rates in different regions (as will be discussed later) it may have contributed to the convergence.

Second, within each region the extensive commodity-price equalization helped raise the terms of trade. Measured as $\left(\mathrm{P}_{\text {iron }} / \mathrm{P}_{\text {flour }}\right)$, Northeast terms of trade rose from just over 6 in 1823 to just under 10 in 1860 . Similarly, measured as $\left(\mathrm{P}_{\text {flour }}\left(\mathrm{P}_{\text {iron }}\right)\right.$, Midwest terms of trade rose from about 0.03 in 1825 to about 0.10 in 1860 . Both Berry (1943) and Cole (1938) corroborate this result for the Midwest with much broader baskets of goods.

\section{Antebellum Factor Prices}

\section{Wage Data: Description and Caveats}

The data on regional wages come from Goldin and Margo (1992), who assembled them from records of United States Army posts which hired civilians. Each month quartermasters reported information about these hires, including pay, the type of jobs, and fringes such as whether rations were provided. To construct wage series from these reports, Goldin and Margo estimate hedonic regressions by region of monthly pay rates on worker characteristics and also location and time dummies. With the coefficients of these regressions, they generate annual series of nominal daily wages averaged by region across all seasons and forts. The series cover three types of labor-artisans, clerks, and laborers--in four regions--Northeast, Midwest, South Atlantic, and South Central. Each series starts in about 1820 and all end in 1856.

The obvious question is how well these wages represent "the market wage" in each region. Margo and Villaflor (1987) argue that the forts did not appear to exercise monopsony power to underpay market wages. Similarly, the forts did not appear to lack the incentive to maximize profits and thus overpay market wages. They find that forts' wages in New York between 1838 and 1843 were very similar to the wages paid along Erie Canal.

\footnotetext{
15 Swank (1892, pp352-353), for example, writes that "this innovation at once caused a revolution in the whole iron industry of the country. Facilities for the manufacture of iron were increased; districts which had been partly closed to this industry because of a scarcity of timber for the supply of charcoal were now fully opened to it; and the cheapening of prices was made possible by the increased production and increased competition ... This introduction [of mineral fuel] marked such radical changes in our iron industry, that we are amply justified in referring to it as a revolution" (italics mine).
} 
These results are somewhat corroborated by other wage data. Using archival sources, Adams (1992) reports average annual nominal wages for common laborers in the western counties of Virginia from 1788 to 1860 . These wages tend to run about $10 \%-50 \%$ lower than Goldin and Margo's laborer wage series for the South Atlantic. Using the Weeks Report, Coelho and Shepherd (1976) report average annual nominal wages for laborers by region from 1851 to 1880 . Although there are very few observations for most year-regions (from one to 34) some of the trends in the Goldin and Margo data appear here as well. For example, in the Weeks data Midwest wages (West North Central) are about 20\%-30\% higher than Middle Atlantic wages.

More work would be helpful here, but in what follows I maintain the assumption that these wages represent regional labor-market conditions. Note that because these wages come mainly from hinterlands, they are more likely to display FPC than if they came from cities. As discussed earlier, commodity prices probably converged more across rural areas than cities. To the extent that this happened, FPC should appear stronger in hinterland wages than in urban wages. Thus, these wages are strong a priori candidates for finding FPC. 16

\section{Wage Data: Methodology}

The convergence of commodity prices provides a benchmark for judging wage convergence. Data on wage convergence in and of themselves do not provide much information about whether wage convergence was "a lot" or "a little." These kinds of comparative statements require some point of reference. The logical point here is commodity prices. The FPC theorem says that commodity and factor prices tend to converge simultaneously: because producers shift resources-and thus factor demands--when commodity prices change, factor prices change then as well. Thus, I assess wage convergence in light of commodity-price convergence.

To look for FPC I look at cross-region trends in nominal wages. It is important to emphasize these are nominal wages, not real wages: as producers reallocate resources in response to changing commodity prices the new factor demands move nominal factor prices. In a wide variety

\footnotetext{
16 Some people have suggested to me that agriculture prices might be a good measure of market wages. The problem with these prices, however, is that they embody not just labor income but also income for capital, land, and other factors which help produce the goods.
} 
of trade models (for example, Samuelson (1949)), complete FPC equalizes across regions nominal factor prices. Clearly, along with equalized commodity prices this implies that real factor prices equalize as well. But real-factor-price convergence need not imply nominal-factor price convergence. The expression for the real-wage ratio between regions $\mathrm{A}$ and $\mathrm{B}$ shows this:

$$
\left(\frac{\omega_{A}}{\omega_{B}}\right)=\left(\frac{W_{A}}{W_{B}}\right) *\left(\frac{P_{B}}{P_{A}}\right)
$$

Real wages can converge even if nominal wages do not as long as commodity prices converge. Thus, to isolate FPC I focus on nominal factor prices. Appendix A discusses this point further.

As with prices, I construct wage ratios across regions to see whether they converge over time towards one. I also construct wage differences across regions to see whether they converge over time towards zero.

\section{Results for Wage Ratios}

After constructing wage-ratio series across regions, I then assumed that for two regions $\mathrm{A}$ and $\mathrm{B}$ their ratio evolves according to

$$
\left(\frac{W_{B}}{W_{A}}\right)_{i t}=A * \exp \left(\beta t \varepsilon_{i t}\right)
$$

where $i$ indexes the labor type, $t$ indexes time, $A$ is the initial ratio at time $t=0, \beta$ is the exponential rate of growth of the series, and $\varepsilon_{i t}$ is the i.i.d. error term that explains noise in the actual ratio around its assumed trend. If the series converges $\beta<0$; if it diverges $\beta>0$. Taking the $\log$ of both sides gives the following log-linear regression specification:

$$
\ln \left(\frac{W_{B}}{W_{A}}\right)_{i t}=\alpha_{i}+\beta t+\varepsilon_{i t} .
$$

With three labor types and four regions there are 18 wage-ratio series altogether. For each series I ran equation (8) using OLS to estimate its $\beta$. In addition, I pooled these series in various ways to form panels for which I estimated one overall $\beta$ using the fixed-effects technique. Here I ran two specifications: all 18 series together and just the series which displayed convergence.

Table 4 reports the results. Also, the top hallves of figures 3 through 5 plot the results for artisans, clerks, and laborers, respectively. As in figures 1 and 2, each graph plots both actual and estimated price ratios against time. 
The results are very different from those obtained for commodity prices. There is no broad pattern of wage ratios converging towards one. Only five series converge at rates at or above the $5 \%$ level of significance; six series converge but at rates not significantly different from zero; four series diverge but at rates not significantly different from zero; and three series diverge at rates at or above the $5 \%$ level of significance. The estimated rates range from -0.0106 to 0.0090 .

When I assume the same underlying process for all labor types and pool them, the estimated rate of convergence is a statistically insignificant -0.0008 : taking all labor varieties together, wage ratios in the antebellum period basically did not converge. Even when I pool only converging series, the estimated overall rate is only -0.0034 . Both these rates are much slower than the rate for prices of approximately -0.01 . No matter which sample of prices and wages is compared, Ftests overwhelmingly reject the null hypothesis of equal convergence rates. For example, pooling all commodity ratios and all labor ratios yields an F-test statistic of 95.67. Excluding the labor ratios which did not converge, the F-test statistic is still 34.13.

Looking again at ratios and half-lives helps demonstrate the economic importance of these different convergence rates. The convergence rate of -0.0008 (ignoring the fact that this rate is not statistically different from zero) implies that a wage ratio in 1860 had fallen to about 97 percent of its 1825 level. Only an initial ratio of about 1.03 fell to 1 , and an initial ratio of 2 fell to only 1.94. For prices, an initial ratio of 1.46 fell to 1 , and an initial ratio of 2 fell to 1.37. Similarly, the halflife of convergence for all wage ratios is approximately 770 years--more than 11 times the half-life for prices.

\section{Results For Wage Differences}

After constructing wage-difference series across regions, I then assumed that for two regions A and $\mathrm{B}$ their ratio evolves according to

$$
\left(\mathrm{W}_{\mathrm{B}}-\mathrm{W}_{\mathrm{A}}\right) \mathrm{it}_{\mathrm{it}}=\mathrm{A} * \exp \left(\beta \mathrm{t} \varepsilon_{\mathrm{it}}\right),
$$

where $i$ indexes the labor type, $t$ indexes time, $A$ is the initial level at time $t=0, \beta$ is the exponential rate of growth of the series, and $\varepsilon_{i t}$ is the i.i.d. error term that explains noise in the actual 
difference around its assumed trend. If the series converges $\beta<0$; if it diverges $\beta>0$. Taking the $\log$ of both sides gives the following log-linear regression specification:

$$
\ln \left(\mathrm{W}_{\mathrm{B}}-\mathrm{W}_{\mathrm{A}}\right) \mathrm{it}=\alpha_{\mathrm{i}}+\beta \mathrm{t}+\varepsilon_{\mathrm{it}} .
$$

With three labor types and four regions there are 18 wage-difference series altogether. For each series I ran equation (10) using OLS to estimate its $\beta$. In addition, I pooled these series in various ways to form panels for which I estimated one overall $\beta$ using the fixed-effects technique. Here I ran two specifications: all 18 series together and just the series which displayed convergence.

Table 5 reports the results. Also, the bottom halves of figures 3 through 5 plot the results for artisans, clerks, and laborers, respectively. As in figures 1 and 2, each graph plots both actual and estimated price differences against time.

Again, the results are very different from those obtained for commodity prices. There is no broad pattern of wage differences converging towards zero. Only one series converges at a rate above the 5\% level of significance; nine series converge but at rates not significantly different from zero; five series diverge but at rates not significantly different from zero; and three series diverge at rates at or above the $5 \%$ level of significance. The estimated rates range from -0.0401 to 0.0889 . For those series which did not converge significantly, the absolute wage differentials across regions ranged from $10 \%$ to well over $50 \%$.

When I assume the same underlying process for all labor types and pool them, the estimated rate of convergence is a statistically insignificant -0.0080 : taking all labor varieties together, wage differences in the antebellum period basically did not converge. Even when I pool only converging series, the estimated overall rate is only -0.0227 . Both these rates are much slower than the rate for prices of approximately -0.04 . No matter which sample of prices and wages is compared, Ftests again overwhelmingly reject the null hypothesis of equal convergence rates.

As with ratios, these results for wage differences are very different from those for prices. The convergence rate of -0.0080 (ignoring the fact that this rate is not statistically different from zero) implies that a wage difference in 1860 had fallen to about 76 percent of its 1825 level. For prices, 
an initial difference had fallen to about $25 \%$ its 1825 level. Similarly, the half-life of convergence for all wage differences is approximately 87 years--more than five times the half-life for prices.

Finally, to emphasize the importance of looking at nominal rather than real wages it is worthwhile to note regional trends in real wages. Margo (1992) constructs real wages by deflating regional nominal wages by regional price indexes constructed from Cole's data. He finds that the ratio of real wages in the Northeast to those in the Midwest for both artisans and laborers was declining towards one, and that in levels real wages in the Northeast grew faster than those in the Midwest. It should be reiterated that real-wage convergence is entirely consistent with a lack of nominal-wage convergence. In this case, commodity-price convergence alone was apparently strong enough to force the real-wage convergence.

Wage Data: Possible Explanations Consistent with FPC

The wage data indicate very little antebellum FPC across regions. Before interpreting the data this way, I discuss two possible limitations of them which might obscure actual FPC.

First, persistent interregional wage differentials might be an artifact of how these data were constructed. In principle this is possible, and it can be checked by comparing them with the data in Margo and Villaflor (1987). From the original Army records Margo and Villaflor construct wage series for clerks and laborers which use different weights in the underlying hedonic regressions. These different weights allow me to check how robust the wages are to different constructions. Wage trends in the Margo and Villaflor data are very similar those in the Goldin and Margo data, so it appears that the results are not driven by data construction.

Second, the wage differentials might reflect interregional differences in labor markets which make equilibrium wages converge to some ratio (difference) other than one (zero). In equilibrium, higher wages in one region might compensate for a variety of factors in that region: higher-quality workers, a longer workday, greater physical danger from disease or attack, greater risk of becoming unemployed, or a higher unemployment rate. If these factors mattered then wages may have converged differently from what I tested. 
Adequately controlling for all these factors is beyond the scope of this paper. But some initial guesses can be made about their importance. First, migration and product-market integration may have been reducing their importance. For example, as more people moved west any "frontier risk" probably diminished. Second, the papers which use these wage series do not mention any evidence of interregional differences in quality, time of work, or physical risk. The underlying fort records might have evidence on these issues. Third, there is evidence that postbellum wages adjusted for unemployment risk and levels: Hatton and Williamson (1991b) find that unskilled workers in Michigan in the 1890s received higher wages facing with a higher likelihood of seasonal unemployment. Unemployment issues might account for some of the antebellum wage differentials, but probably not all of them. For example, laborer wages tended to be higher in the Midwest. But with this region's rapid migration and output growth, it likely had relatively low levels and risks of unemployment. Data on regional employment patterns would help clarify these issues.

Overall, then, correct interpretation of the wages depends on their robustness and on the possibility that interregional differences in equilibrium labor-market conditions prevented wages from fully equalizing. Insofar as the data are robust that these conditions did not matter, the data show very little FPC across regions.

\section{Other Factor-Price Data}

Unfortunately, I cannot corroborate the results for wages with rental rates on land because these data do not exist. According to Lindert (1988), reliable land prices date back to only 1850 when the Department of Agriculture was founded. However, a proxy for regional capital prices does exist. Bodenhorn and Rockoff (1992) construct an interest rate, the rate of return on earning assets, from bank financial records kept by state legislatures. Similarly, Bodenhorn (1992) constructs southem interest rates from prices for bills of exchange.

Their results seem broadly in line with the results for wages. They do find strong evidence of intraregional capital-market integration, especially in the Northeast among Boston, New York, and Philadelphia. But the evidence across regions is mixed. Bodenhorn finds that southern interest 


\section{References}

Adams, Donald R., "Prices and Wages in Antebellum America: The West Virginia Experience," The Journal of Economic History, March 1992, pp 206-216.

Atack, Jeremy, "Economies of Scale and Efficiency Gains in the Rise of the Factory in America," in Peter Kilby (ed) Quantity \& Quiddity, Middletown: Wesleyan U. Press, 1987, pp 286-335.

Berry, Thomas, Western Prices Before 1861, Cambridge: Harvard University Press, 1943.

Bodenhorn, Howard and Rockoff, Hugh, "Regional Interest Rates in Antebellum America," in Claudia Goldin and Hugh Rockoff (eds) Strategic Factors in 19th Century American Economic History, University of Chicago Press: Chicago, 1992, pp 159-188.

Caves, Richard E., Trade and Economic Structure, Cambridge: Harvard University Press, 1960.

Coelho, Philip R., and James F. Shepherd, "Regional Differences in Real Wages: The United States, 1851-1880," Explorations in Economic History, 1976, pp 203-230.

Cole, Arthur H., Wholesale Commodity Prices in the United States, 1700-1861, Cambridge: Harvard University Press, 1938.

Davis, Lance, and H. Louis Stettler, "The New England Textile Industry, 1825-1860," in Dorothy S. Brady (ed) Output, Employment, and Productivity in the United States After 1800, New York: Columbia University Press, pp 213-238.

Fishlow, Albert, American Railroads and the Transformation of the Antebellum Economy, Cambridge: Harvard University Press, 1965.

Goldin, Claudia and Margo, Robert A., "Wages, Prices, and Labor Markets Before the Civil War," in Claudia Goldin and Hugh Rockoff (eds) Strategic Factors in 19th Century American Economic History, University of Chicago Press: Chicago, 1992, pp 67-104.

Hatton, Timothy J., and Jeffrey G. Williamson, "Integrated and Segmented Labor Markets: Thinking in Two Sectors," The Journal of Economic History, June 1991, pp 413-425.

Hatton, Timothy J., and Jeffrey G. Williamson, "Unemployment, Employment Contracts, and Compensating Wage Differentials," The Journal of Economic History, Sept. 1991, pp 605-632.

Hatton, Timothy J., and Jeffrey G. Williamson, "Wage Gaps Between Farm and City: Michigan in the 1890s", Explorations in Economic History, October 1991, pp 381-408.

Heckscher, Eli F., and Bertil Ohlin, "The Theory of Trade," in Henry Flam and M. June Flanders (eds) Heckscher-Ohlin Trade Theory, Cambridge: The MIT Press, 1991.

James, John, "The Development of the National Money Market," The Journal of Economic History, December 1976, pp 878-897.

Leamer, Edward E., "The Heckscher-Ohlin Model in Theory and Practice," Princeton Studies in International Finance Working Paper \#77, February 1995. 
Lindert, Peter H., "Long-Run Trends in American Farmland Values", Working Paper \#45, Agricultural History Center, University of California, Davis, 1988.

Margo, Robert A., "Wages and Prices During the Antebellum Period," in Robert E. Gallman and John Joseph Wallis (eds) American Economic Growth and Living Standards Before the Civil War, Chicago: The University of Chicago Press, 1992, pp 173-210.

Margo, Robert A. and Villaflor, Georgia C., "The Growth of Wages in Antebellum America: New Evidence," The Journal of Economic History, Volume 47, Number 4, 1987, pp 873-895.

North, Douglass C., The Economic Growth of the United States, 1790 to 1860 , Englewood Cliffs, N.J.: Prentice-Hall, Inc., 1961.

O'Rourke, Kevin, and Jeffrey G. Williamson, "Late Nineteenth-Century Anglo-American FactorPrice Convergence," The Journal of Economic History, December 1994, pp 892-916.

Rosenbloom, Joshua L., "Occupational Differences in Labor Market Integration: The United States in 1890," The Journal of Economic History, June 1991, pp 427-439.

Rosenbloom, Joshua L., "One Market or Many? Labor Market Integration in the Late NineteenthCentury United States, The Journal of Economic History, March 1990, pp 85-106.

Rothenberg, Winifred B., "The Emergence of Farm Labor Markets and the Transformation of the Rural Economy," The Journal of Economic History, September 1988, pp 537-566.

Samuelson, Paul, "International Factor-Price Equalization Once Again," The Economic Journal, June 1949, pp 181-197.

Samuelson, Paul, "The Transfer Problem and Transport Costs, II: Analysis of Effects of Trade Impediments," The Economic Journal, June 1954, pp 264-289.

Slaughter, Matthew J., "International Trade, Multinational Corporations, and American Wages," Ph.D. Dissertation, MIT, April 1994.

Sokoloff, Kenneth L., "Invention, Innovation, and Manufacturing Productivity Growth in the Antebellum Northeast, in Gallman and Wallis (eds) American Economic Growth and Living Standards Before the Civil War, Chicago: The University of Chicago Press, 1992, pp 345-384.

Sokoloff, Kenneth L., and Georgia C. Villaflor, "The Market for Manufacturing Workers During Early Industrialization," in Claudia Goldin and Hugh Rockoff (eds) Strategic Factors in 19th Century American Economic History, University of Chicago Press: Chicago, 1992, pp 29-65.

Swank, James M., A History of the Manufacture of Iron in All Ages, Burk Franklin: New York, 1892.

Taylor, George Rogers, The Transportation-Revolution: 1815-1860, Holt, Rinehart, and Winston: New York, 1951.

The 8th Census of the United States, Washington, D.C.: Government Printing Office, 1862.

Williamson, Jeffrey G. and Lindert, Peter H., American Inequality: A Macroeconomic History, Academic Press: New York, 1980. 
rates closely tracked those in the Northeast. But Bodenhorn and Rockoff find that the level difference in interest rates across the Northeast and Midwest was increasing. The level premium of Midwest rates over New York City rates was as follows: $2.86 \%$ in $1835,2.03 \%$ in $1840,2.44 \%$ in $1845,3.83 \%$ in 1850 , and $5.02 \%$ in 1855 (Table 5.11, p.185). Like wages, capital prices seem to have converged across some regions but diverged across others. This makes wages seem representative of all antebellum factor prices.

\section{Explaining the Lack of FPC}

The task now becomes explaining why interregional convergence of commodity prices did not lead to a similar convergence of factor prices. As Leamer says, the "challenge" in applying the FPC theorem lies in finding combinations of endowments and technologies which generate FPC. Apparently, antebellum America was not such a combination. I argue that interregional differences in both endowments and technologies very likely prevented FPC.

\section{Factor Endowments, Production Patterns, and FPC}

The theory here is very simple. Differences in factor endowments across regions can lead each region to make only a subset of all goods, in which case regional factor demands need not adjust to commodity-price convergence in a way which converges factor prices as well.

A quick example can explain this result. Consider a world with two regions, Northeast and Midwest; two goods, agriculture and manufactures; and two factors, labor and land. Suppose that agriculture (manufacturing) employs land (labor) relatively intensively. Finally, suppose that the Midwest is so well endowed with land that it produces only agriculture. This requires that Midwest's relative endowment lie outside the "cone of diversification" determined by the two production technologies: i.e., that the Midwest have so much land that it cannot fully employ all this land using the integrated-equilibrium production techniques. The Midwest exports food and the Northeast manufactures.

Now reduce interregional transportation costs. As commodity prices converge, in each region the terms of trade rise. In the Northeast, producers respond by shifting resources out of agriculture and into manufacturing. This raises demand for labor relative to land, so wages rise 
and land rents fall. This is the standard Stolper-Samuelson result: resources shift across industries as relatives prices move, and this shifts relative factor demands and thus factor prices. In the Midwest, however, because there is only one industry the Stolper-Samuelson theorem does not apply. Instead, higher agriculture prices raise demand and thus prices for both factors.

Overall, the transportation revolution raises wages in both regions. The ratio of and difference between wages across regions can fall, rise, or stay constant, depending on the increase in each region. Thus, differences in regional factor endowments can prevent FPC. In this case, specialization prevents commodity-price convergence from inducing shifts in regional factor demands needed to converge factor prices as well. Note that specialization does not prevent commodity-price convergence: this requires just the ability to arbitrage by shipping goods among regions, independent of the regions' production patterns. Appendix B develops this story more completely.

Tables 6 and 7 provide some empirical support for this story. They summarize information on production in 1850 and 1860 as recorded in the 1860 Census (I could not locate production data for any earlier years than this). Table 6 documents which Midwest states in 1850 and 1860 did not produce any of the 14 manufacturing products listed. In 1850 five of the products were not produced anywhere in the Midwest, and in 1860 three were not. The remaining products had varying numbers of states which made none of them. And presumably, in the years before 1850 even more products were not produced in the Midwest. This evidence is consistent with the idea that the Midwest was so poorly endowed with capital and/or land that it did not produce many manufactures. Beyond the Midwest, there are many other examples of goods not produced in other regions. For example, ginned çotton was produced only in the South in 1850 and 1860.

This is not to say that the Midwest produced no manufactures at all. Table 7 breaks down the output value between agriculture and manufactures for both the Midwest and the Northeast. I Stress that these are estimates: the censuses does not report comprehensive data for agriculture, and for many foodstuffs it reports physical quantities only. To estimate the value of these 
foodstuffs I used their average annual wholesale prices as reported in Cole (1938). ${ }^{17}$ Table 7 indicates that from 1850 to 1860 the Northeast's share of manufacturing rose from $60.3 \%$ to $66.2 \%$. But in both years only about $20 \%$ of Midwest production was in manufacturing. And because the censuses may have missed some agricultural output, these manufacturing shares are upper-bound estimates. Before 1850, manufacturing's share in the Midwest was probably even lower. Again, this is consistent with differences in regional endowments. The Midwest was so well endowed with land that it produced largely agriculture, while the Northeast shifted towards manufacturing as it accumulated relatively more capital.

Taken together, Tables 6 and 7 indicate that differences in regional endowments led regions to produce different sets of products. ${ }^{18}$ This probably helped prevent FPC.

\section{Production Technologies and FPC}

The theory here is also very simple. Across regions, differences in production technology which lead to different marginal productivities for factors generate different factor prices even when commodity prices are fully equalized.

Consider the example of Hicks-neutral technology differences across regions. Suppose that two regions produce one good, $Q$, with labor under constant returns to scale according to

$$
\mathrm{Q}_{\mathrm{i}}=\Theta_{\mathrm{i}} \mathrm{L}_{\mathrm{i}},
$$

where $\mathrm{i}$ indexes regions $\mathrm{A}$ and $\mathrm{B}$ and $\Theta$ is the Hicks-neutral technology parameter. Under free trade $\mathrm{P}_{\mathrm{A}}=\mathrm{P}_{\mathrm{B}}$, and this implies that

$$
\frac{w_{A}}{w_{B}}=\frac{\Theta_{A}}{\Theta_{B}}
$$

17 Dollar values are reported for four products: livestock, market gardens, orchard products, and slaughtered animals. Only physical quantities are reported for ten others: butter, corn, ginned cotton, hops, molasses, rice, sugar, tobacco, wheat, and wine.

${ }^{18}$ These results corroborate Berry (1943), North (1961), and Taylor (1951). Taylor (p169) marvels at "the growing territorial specialization upon which rested the striking growth of American domestic commerce during the period of this study [1815-1860]." Similarly, North (p136) argues that "During these surges of westward expansion, their primary importance for American economic growth ... was that he [the Midwest farmer] became more specialized ... Throughout the period of study [1790 to 1860], the region's factor endowments provided an obvious comparative advantage for agricultural products, specifically wheat and corn." And Berry (p226) argues that transportation was a key agent of specialization. "Railroads ... encouraged the direct shipment of hogs to eastem markets. This development, which parallels the growth of long-distance traffic in wheat and com, wrought steady if gradual effect of specialization." 
When $\Theta_{A}=\Theta_{B}$ factor prices fully converge, but when $\Theta_{A} \neq \Theta_{B}$ they do not. Instead the more productive factor receives a higher wage.

More generally, consider any good, $Q$, for which production functions differ across regions:

$$
Q_{A}=F\left(L_{A}, \ldots\right) \text { and } Q_{B}=G\left(L_{B}, \ldots\right) \text {, }
$$

where $\mathrm{F}$ and $\mathrm{G}$ differ for any number of reasons: Hicks-neutral technology parameters, inputs employed, intensity of input use, $x$-inefficiencies, etc. Suppose that in each region labor earns its marginal revenue product and that free trade again sets $\mathrm{P}_{\mathrm{A}}=\mathrm{P}_{\mathrm{B}}$. Then

$$
\frac{w_{A}}{w_{B}}=\frac{F_{L A}}{G_{L B}} \text {, }
$$

where $F_{L A}$ is the marginal physical product of labor in region A and similarly for $B$. Again, wages fully converge if and only if labor's marginal physical product is the same in both regions. When this condition does not hold because of technology differences, FPC need not occur.

There is empirical evidence that regional technology differences helped prevent FPC. Davis and Stettler (1966) find that a large productivity gap separated most antebellum textile operations from those which employed the industry's "best practices." They argue that most operations lagged because they incorporated new inputs (such as steam-driven belt drives for spindles) very slowly. Sokoloff (1992) argues that the antebellum Northeast attained much higher manufacturing productivity than other regions because it also generated much higher patent rates per capita. And Atack (1987) finds that many antebellum industries displayed a bimodal distribution of firms with a few productive firms producing a large share of industry output and a lot of small firms producing a small share of industry output.

Taken together, this evidence indicates that antebellum production technologies differed quite a bit across regions. This probably helped prevent FPC.

\section{Conclusion}

In this paper I have studied whether the construction canals and railroads in antebellum America led to FPC across regions. The basic answer is no: canals and railroads converged commodity prices across regions, but this did not lead to factor-price convergence. Two likely explanations of this are interregional differences in factor endowments and in production 
technologies. This finding underscores the fact that the FPC theorem does not have unambiguous empirical predictions. How commodity prices feed into factor prices depends crucially on parameters such as endowments and technology.

The integration of antebellum labor markets, then, seems to have been driven by the supplyside story of migration. One possible extension of this work would link more closely particular transportation innovations to changes in commodity and factor prices. This work might identify how quickly innovations affected markets. A second possible extension would look for FPC in the postbellum period. During this time the Midwest developed its manufacturing sector by accumulating capital and know-how; perhaps major changes like these made FPC possible.

\section{Appendix A: FPC and Nominal Versus Real Wages}

It is important to clarify that for a lot of models the FPC theorem implies cross-country equalization of nominal factor prices. Looking at real factor prices alone is not sufficient. This appendix proves one commonly used set of conditions under which convergence in levels of commodity prices across regions leads to convergence in levels of nominal factor prices across regions.

Consider two regions, 1 and 2; two goods, A and B; and two factors of production, $\mathrm{L}$ and $\mathrm{K}$, which receive respective factor payments $w$ and $r$ and which are perfectly mobile across industries within each region. Production technology for each good is identical across both regions and is linear homogeneous in the inputs. Linear homogeneity implies two important facts. The first is that the slopes of production isoquants in $(L, K)$ space are constant along rays extending from the origin (this actually requires only that the production functions be homothetic, but all homogeneous functions are homothetic as well). The second is that marginal physical productivities for each good depend only on the ratio of factors employed and not their levels. This is a simple application of Euler's Theorem.

Start with the claim that under sufficient assumptions, commodity-price equalization implies equalization of relative factor prices across 1 and $2:(w / r)_{1}=(w / r)_{2}$. Samuelson $(1949)$ proves 
this one-to-one mapping from relative commodity prices to relative factor prices. But this statement in and of itself is not what is trying to be proved. Next, combine this claim with the two technology facts. $(w / r)_{1}=(w / r)_{2}$ plus the first fact implies that relative factor employment in each industry is equalized across 1 and $2:(K / L)_{1 A}=(K / L)_{2 A}$ and $(K / L)_{1 B}=(K / L)_{2 B}$. This statement plus the second fact implies that the levels of marginal physical productivities (mpp) for each factor in each industry are equalized across 1 and $2: \mathrm{mpp}_{\mathrm{ij} 1}=\mathrm{mpp}_{\mathrm{ij} 2}$ for $\mathrm{i}=\mathrm{L}, \mathrm{K}$ and $\mathbf{j}=\mathrm{A}, \mathrm{B}$. Each factor's nominal wage in industry $j$ is its marginal revenue product in that industry: $P_{j} \times m_{i j}$. It

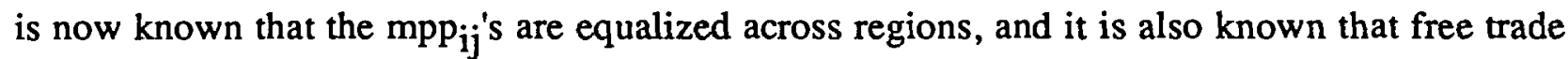
equalizes the $\mathrm{P}_{j}$ 's across regions. It immediately follows that nominal wages in each industry are equalized across regions. And thanks to perfect inter-industry factor mobility, nominal wages in each region are equalized across industries. Thus, one world nominal wage and one world nominal rental rate emerge: in every industry in every region, free trade ensures that the same nominal price is paid to every factor.

This discussion demonstrates that one reasonable empirical test for FPC is whether nominal factor prices across regions are converging. This is the test used in the paper.

\section{Appendix B: Factor Endowments, Production Patterns, and FPC}

Explaining how differences across regions in endowments can prevent FPC can be done most easily in a $2 \times 2 \times 2$ model. Consider two regions, Northeast (E) and Midwest (W); two goods, agriculture (A) and manufactures (M); and two factors, labor (L) and land (K), with respective factor prices $w$ and r. Production technology for each good exhibits constant returns to scale; moreover, $\mathrm{A}$ employs $\mathrm{K}$ relatively. intensively and $\mathrm{M}$ employs $\mathrm{L}$ relatively intensively. This production technology can be represented with unit-cost-function duals, $C_{A}(w, r)$ and $C_{M}(w, r)$.

Transportation technology takes the form of "iceberg" shipping costs for food (see Samuelson (1954)). ${ }^{19}$ When an amount $\mathrm{m}$ of agriculture is shipped, some of it "melts" in transit to pay for the

\footnotetext{
${ }^{19}$ Another transportation cost could also be applied to $\mathrm{M}$, but it adds nothing to the analysis. Thus, for simplicity all transportation costs are subsumed into A. Empirically, falling transportation costs probably moved prices in agriculture more than manufactures because agricultural products were more bulky.
} 
shipping such that only a fraction $(t * m)$ arrives, where $t \in(0,1)$. Agricultures are non-tradable when $\mathrm{t}=0$ and are freely tradable when $\mathrm{t}=1$. Thus, the antebellum transportation revolution can be represented by $\mathrm{d}>0$. Given this transportation technology, arbitrage in goods trade ensures the following two equilibrium conditions.

$$
\text { (A1) } \mathrm{P}_{\mathrm{AW}}=\mathrm{tP}_{\mathrm{AE}}
$$

(A2) $\quad P_{M W}=P_{M E}=1$ (by designating manufactures the numeraire)

Finally, assume that region $\mathrm{W}$ specializes in $\mathrm{A}$. It is endowed with $\mathrm{L}_{\mathrm{W}}$ labor and $\mathrm{K}_{\mathrm{W}}$ land; similarly, region $\mathrm{E}$ is endowed with $\mathrm{L}_{\mathrm{E}}$ labor and $\mathrm{K}_{\mathrm{E}}$ land. Specialization requires that W's relative endowment lie outside the "cone of diversification" determined by the two production technologies. This means that $\left(\mathrm{K}_{\mathrm{W}} / \mathrm{L}_{\mathrm{W}}\right)$ is sufficiently large that $\mathrm{W}$ cannot fully employ all its land using the integrated-equilibrium production techniques, and thus that $\mathrm{W}$ makes only $\mathrm{A}$. In contrast, $\left(\mathrm{K}_{\mathrm{E}} / \mathrm{L}_{\mathrm{E}}\right)$ lies within the cone of diversification such that $\mathrm{E}$ produces both goods.

The equilibrium production configuration in each region can be represented with the dual of the Lerner-Pearce diagram. Initially, consider each region in 1820.

Figure 6 plots the initial equilibrium for region $E$ in $\left(w_{E}, r_{E}\right)$ space. The curve labeled " $A A$ " is E's zero-profit locus for $A$ which traces out combinations of $w_{E}$ and ${ }_{E}$ along which ${ }_{\mathrm{AE}}=$ $\mathrm{C}_{\mathrm{AE}}(\mathrm{w}, \mathrm{r}){ }^{20} \mathrm{~A}$ rise in $\mathrm{P}_{\mathrm{AE}}$ shifts the locus proportionately outward along every ray through the origin. Similarly, the curve labeled "MM" is E's zero-profit locus for $M$ which traces out combinations of $w_{E}$ and $r_{E}$ along which $P_{M E}=1=C_{M E}(w, r)$. The $M M$ locus has a steeper slope because $\mathrm{M}$ uses $\mathrm{L}$ relatively intensively. For each locus, the absolute value of its slope at a point indicates the ratio of labor to land employed in that industry given that point's factor prices.

Because production technologies involve no factor-intensity reversals, the two loci intersect once and only once. The intersection point $X$ determines the levels of $w_{E}$ and $r_{E}$ which are consistent with positive production in both industries. At X, the relative-employment ratios in A

\footnotetext{
${ }^{20}$ The equation which defines the $P_{A E}=C_{A E}(w, \tau)$ locus is given by a ${ }_{L A}{ }^{w}{ }+a_{K A}{ }^{T}=P_{A E}$. Here, a ${ }_{L A}$ and a $K A$ represent the amounts of labor and land needed to produce one unit of $A$. Where substitutability among factors is possible, these amounts are themselves functions of the factor prices. In particular, with linear homogeneous technology, they depend only on the ratio of factor prices. Thus, the curve is convex to the origin because as the wage-rental ratio rises $A$ producers employ a higher mix of land to labor.
} 
and $M$ are given by the rays $-(L / K)_{A}$ and $-(L / K)_{M}$, respectively. The two cones formed by these rays which radiate in either direction from $\mathrm{X}$ constitute the cone of diversification. If region E's aggregate relative endowment drawn through $\mathrm{X}$ lies within this cone, then $\mathrm{E}$ can produce both goods and still fully employ E's total endowment. In this situation, $\mathrm{X}$ represents the equilibrium factor prices. $E^{\prime} s$ endowment ray is drawn as $-\left(\mathrm{L}_{\mathrm{E}} / \mathrm{K}_{\mathrm{E}}\right)$, and because it does lie within the cone of diversification $\mathrm{X}$ represents E's equilibrium.

Figure 7 plots the initial equilibrium for region $\mathrm{W}$ in $\left(\mathrm{W}_{\mathrm{W}}, \mathrm{r}_{\mathrm{W}}\right)$ space on the assumption that $\mathrm{W}$ was already specialized in agriculture in 1820 . The AA locus represents combinations of $\mathrm{w}_{W}$ and $r_{W}$ along which $P_{A W}={ } P_{A E}=C_{A W}(w, r)$. Similarly, the $M M$ locus represents combinations of ${ }^{w} W$ and $r_{W}$ along which $P_{M W}=P_{M E}=1=C_{M W}(w, r)$. The main difference from the previous figure is that here, $W$ 's endowment ray $-\left(\mathrm{L}_{\mathrm{W}} / \mathrm{K}_{\mathrm{W}}\right)$ lies outside the cone of diversification. This means that production of both goods is inconsistent with full employment: $\mathrm{W}$ has too much $\mathrm{K}$. To fully employ all this $\mathrm{K}, \mathrm{W}$ must specialize in the $\mathrm{K}$-intensive good, $\mathrm{A}$. In this situation $\mathrm{X}$ does not represent the equilibrium factor prices. Instead, equilibrium is determined by the point $Y$ at which the slope of the AA locus equals $-\left(\mathrm{L}_{\mathrm{W}} / \mathrm{K}_{\mathrm{W}}\right)$.

The effect of the transportation revolution on regional factor prices can be analyzed in these diagrams. Building canals and railroads can be modeled as a rise in $t$ towards one. Under very general technology and preference conditions, this rise generates commodity-price equalization by raising $\mathrm{P}_{\mathrm{AW}}={ }_{\mathrm{T}} \mathrm{P}_{\mathrm{AE}}$ and lowering $\mathrm{P}_{\mathrm{AE}^{--}}$just as was observed in the data.

The expenditure-revenue framework can help demonstrate this generality. Let there be one representative consumer and producer in each region, so that each region's consumption and production can be summarized in a single expenditure and revenue function, respectively. Moreover, thanks to identical preferences and technology across regions, functional forms are the same in both regions. Let the revenue function be given by $r$ (prices, endowments), and the expenditure function by e(prices, utility). These functions are assumed to have the standard properties. Let $\mathrm{v} \equiv \mathrm{W}$ 's endowment vector, $\mathrm{V} \equiv \mathrm{E}^{\prime}$ 's endowment vector, $\mathrm{u} \equiv \mathrm{W}$ 's utility, and $\mathrm{U} \equiv$ 
E's utility. Three equations (not four, thanks to Walras' law) can characterize the antebellum general equilibrium.

$$
\text { (A3) } \quad \mathrm{e}(\mathrm{tP}, 1, \mathrm{u})=r(\mathrm{tP}, 1, \mathrm{v})
$$

This equation says that expenditure equals revenue in $W$ (where each is measured in units of $M$ ). Here I have simplified $\mathrm{PAE}$ to just $\mathrm{P}$. An analogous equation holds for $\mathrm{E}$.

$$
\text { (A4) } \quad e(P, 1, U)=r(P, 1, V)
$$

Finally, the system needs one goods-market clearing condition. Take good A: in equilibrium, world demand equals world supply. The point to remember for this condition is that some $A$ disappears in transit from $\mathrm{W}$ to $\mathrm{E}$ as transportation costs. To quantify how much, let $\mathrm{m}(\mathrm{tP}, \mathrm{u}) \equiv$ $r_{t P}(t P, 1, v)-e_{t P}(t P, 1, u)$ be the (scalar) amount of $A$ that $W$ exports to $E$. Then the fraction (1-t)m gets used up as transportation costs and cannot be consumed. The goods-market clearing condition needs to account for this amount.

$$
\text { (A5) } \quad e_{t P}(t P, 1, u)+e_{P}(P, 1, U)=r_{t P}(t P, 1, v)+r_{P}(P, 1, V)-(1-t) m(t P, u)
$$

In this model, the transportation revolution can be represented as $d>0$. To show under what conditions this $\mathrm{dt}>0$ leads to $\mathrm{dP}>0$, totally differentiate (A3)-(A5) and solve for $\mathrm{dP}$. Total differentiation yields the following equations.

$$
\begin{gathered}
\left(A 3^{\prime}\right) e_{t P}(t d P+P d t)+e_{u} d u=r_{t P}(t d P+P d t) \\
\left(A 4^{\prime}\right) \quad e_{P} d P+e_{U} d U=r_{P} d P \\
\left(A 5^{\prime}\right) e_{t P t P}(t d P+P d t)+e_{t P u} d u+e_{P P} d P+e_{P U} d U= \\
r_{t P t P}(t d P+P d t)+r_{P P} d P+(t-1) m_{t P}(t d P+P d t)+(t-1) m_{u} d u+m d t
\end{gathered}
$$

Equations (A3')-(A5') contain three endogenous variables: $d u, d U$, and $d P$. Solving for $d P$ generates the following expression.

$$
d P=\frac{d t * P\left(r_{t P t P}-e_{t P t P}\right)+d t * \frac{P e_{t P u}\left(e_{t P}-r_{t P}\right)}{e_{u}}+d t * P(t-1) m_{t P}+d t * \frac{P(t-1) m_{u}\left(r_{t P}-e_{t P}\right)}{e_{u}}+d t * m}{t\left(e_{t P t P}-r_{t P t P}\right)+\left(e_{P P}-r_{P P}\right)+\frac{t e_{t P u}\left(r_{t P}-e_{t P}\right)}{e_{u}}+\frac{e_{P u}\left(r_{P}-e_{P}\right)}{e_{u}}+t(1-t) m_{t P}+\frac{t(t-1) m_{u}\left(r_{t P}-e_{t P}\right)}{e_{u}}}
$$


The expenditure and revenue functions have the following properties: $e_{P}>0, e_{P P}>0, e_{u}>0$, $e_{\mathrm{Pu}}>0, \mathrm{r}_{\mathrm{P}}>0$, and $\mathrm{r}_{\mathrm{PP}}>0$. Moreover, differentiating $\mathrm{m}(\cdot)$ and using these properties shows that $m_{t P}=\left(r_{t P t P}-e_{t P t P}\right)<0$ and $m_{u}=-e_{t P u}<0$. With this information, the expression for $\mathrm{dP}$ can be signed. It can be shown that $\mathrm{dP}>0$ if and only if $e_{\mathrm{P}}>r_{\mathrm{P}}$. Because $\mathrm{e}(\cdot)$ is concave in $\mathrm{P}$ and $\mathrm{r}(\cdot)$ is convex in $\mathrm{P}$, this condition clearly holds over some non-trivial range of $\mathrm{P}$ for any functional form of $\mathrm{e}(\cdot)$ and $\mathrm{r}(\cdot)$. Thus, $\mathrm{d}>0$ leads to $\mathrm{dP}<0$ under very general conditions.

The only remaining point to demonstrate is that the Midwest price of agriculture, $P_{A W}=t P$, rises. Totally differentiating this expression yields $\mathrm{dP}_{\mathrm{AW}}=\mathrm{tdP}+\mathrm{Pdt}$. On the right-hand side, the first term is negative and the second term is positive. Thus, $\mathrm{dP}_{\mathrm{AW}}>0$ requires only that Pdt be greater than (-tdP).

Given this result for the movement in prices, Figure 8 traces the effects in $E$ of a fall in $P_{A E}$. The AA locus moves in to $\mathrm{A}^{\prime} \mathrm{A}^{\prime}$. The $\mathrm{A}^{\prime} \mathrm{A}^{\prime}$ and $\mathrm{MM}$ loci intersect at $\mathrm{X}^{\prime}$; tangents of each locus drawn through this point form E's new cone of diversification. $E$ 's endowment ray $-\left(L_{E} / K_{E}\right)$ through $\mathrm{X}^{\prime}$ lies within this cone, so $\mathrm{E}$ remains diversified and $\mathrm{X}^{\prime}$ represents $\mathrm{E}$ 's new equilibrium. At $X^{\prime}, r_{E}$ has fallen to ${ }^{E}{ }^{\prime}$ and $w_{E}$ has risen to $w_{E}^{\prime}$. This is the standard Stolper-Samuelson result: resources shift across industries as relatives prices move, and this shifts relative factor demands and thus factor prices. Region-wide, the demand for the factor used relatively intensively in manufacturing, labor, increases and the demand for the factor used relatively unintensively in manufacturing, land, decreases.

Figure 9 traces the effects in $W$ of a rise in ${ }^{P} P_{A E}$. The $A A$ locus moves out to $A^{\prime} A^{\prime}$. $A^{\prime} A^{\prime}$ intersects $M M$ at $X$ ', but $W ' s$ aggregate endowment ray $-\left(\mathrm{L}_{\mathrm{W}} / \mathrm{K}_{\mathrm{W}}\right)$ lies outside the cone of diversification at $X^{\prime}$. Thus, $\mathrm{W}$ remains specialized in agriculture, and its new equilibrium is determined by the point $Y^{\prime}$ at which the slope of the $A^{\prime} A^{\prime}$ locus equals $-\left(L_{W} / K_{W}\right){ }^{21}$ At $Y^{\prime}$, both factor prices are have risen: $r_{W}$ to ${ }{ }_{W}$, and ${ }^{w}{ }_{W}$ to $w_{W}$ '. Because of specialization, the rise in

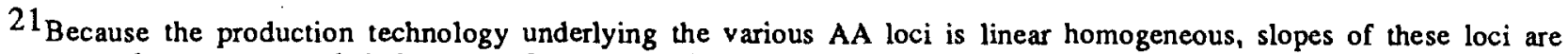
constant along rays extended along rays from the origin. Thus, because the endowment ray has the same slope at $Y$ and $Y^{\prime}$, $Y^{\prime}$ can be found along $A^{\prime} A^{\prime}$ by extending a ray from the origin through $Y$. In Figure 13, the ray extended from the origin demonstrates this point.
} 
${ }^{t P} \mathrm{AE}$ does not induce a Stolper-Samuelson shift in factor demands away from labor and toward land. Instead, demand and thus the price for both factors rises.

To see this algebraically, remember that each factor in Midwest A production receives a price equal to its marginal revenue product, which equals ${ }^{P} P_{A E}$ multiplied by the factor's marginal physical product (mpp). Across equilibria, the mpp's are fixed because total $\mathrm{W}$ endowment is always employed in agriculture and because linear-homogeneous agriculture technology implies that mpp's depend only on relative factor employment (see Appendix A on this point). So a higher $\mathrm{tP}_{\mathrm{AE}}$ immediately raises the price of both factors.

Together, figures 8 and 9 demonstrate that the transportation revolution raises nominal wages in both $\mathrm{E}$ and $\mathrm{W}$. As a result, the ratio $\left(\mathrm{w}_{\mathrm{E}} / \mathrm{w}_{\mathrm{W}}\right)$ can remain constant. Specialization in $\mathrm{W}$ can explain why commodity-price convergence did not lead to factor-price convergence.

At least three other empirical facts about antebellum America can be explained in this framework as well. First are regional differences in wage levels. Figures 3 through 5 indicate that artisan and laborer wages were approximately $20 \%$ higher in the Midwest while clerical wages were approximately $40 \%$ higher in the Northeast. The model assumes that $\left(\mathrm{K}_{W} / \mathrm{L}_{W}\right)>\left(\mathrm{K}_{E} / \mathrm{L}_{E}\right)$ : $\mathrm{W}$ is relatively well endowed in land while $\mathrm{E}$ is relatively well endowed in labor. These relative endowments imply that before the transportation revolution (i.e., under autarky), $w_{W}>w_{E}$ and $r_{W}<r_{E}$. This can explain the higher Midwest artisan and laborer wages. However, it cannot explain higher Northeast clerical wages.

A second antebellum fact which can be explained is the divergence ${ }^{-}$of regional interest rates. Suppose that $r$, the rate of return on land, can be interpreted as a rate of return on bank assets: land is one possible bank asset, and in equilibrium all these assets earn roughly the same rate of return. The Learner-Pearce diagrams predict two things about regional interest rates: 'that canals and railroads should raise $r_{W}$ and lower $r_{E}$, and that initial endowments imply that in $1820 r_{E}>r_{W}$. These two facts together imply that regional interest rates should have been converging. However, Bodenhorn and Rockoff (1992) give reason to believe that in $1820 \mathrm{r}_{\mathrm{W}}>\mathrm{r}_{\mathrm{E}}$. Their data indicate that as far back as $1830, \mathrm{r}_{\mathrm{W}}>\mathrm{r}_{\mathrm{E}}$, not vice versa. They call this premium a "frontier effect" caused 
in part by greater monitoring costs of Midwestern investments. If in fact ${ }^{{ }_{W}}>r_{E}$ initially, then canals and railroads should have triggered even greater divergence.

The third fact which can be explained is continued Midwest specialization despite factor accumulation. As $\left(\mathrm{K}_{\mathrm{W}} / \mathrm{L}_{\mathrm{W}}\right)$ changes, the $-\left(\mathrm{L}_{\mathrm{W}} / \mathrm{K}_{\mathrm{W}}\right)$ ray in Figure 9 rotates. When drawn through $\mathrm{X}$, manufacturing production begins if the ray moves back into the cone of diversification. I have assumed that this did not occur--i.e., that land accumulation was sufficient to keep the $-\left(\mathrm{L}_{\mathrm{W}} / \mathrm{K}_{\mathrm{W}}\right)$ ray below the cone of diversification. Thus, specialized production continues at points such as $Y^{\prime}$. As unbalanced accumulation occurs, however, $Y^{\prime}$ shifts. For example relatively greater labor accumulation would steepen the $-\left(\mathrm{L}_{\mathrm{W}} / \mathrm{K}_{\mathrm{W}}\right)$ ray and thereby slide $\mathrm{Y}^{\prime}$ up and to the left. This would dampen the rise in $\mathrm{w}_{\mathrm{W}}$ and would reinforce the rise in $\mathrm{r}_{\mathrm{W}}$. Geometry makes clear that given the shift in the AA locus out to $\mathrm{A}^{\prime} \mathrm{A}^{\prime}$ caused by the transportation revolution, there exists a range of shifts in $\left(\mathrm{K}_{\mathrm{W}} / \mathrm{L}_{\mathrm{W}}\right)$ which will be insufficient to completely offset either of the factor-price rises triggered by the shift to $\mathrm{A}^{\prime} \mathrm{A}$ '. Thus, although no land-supply data exist to determine the nature of Midwest factor accumulation, unbalanced factor accumulation can be consistent with all Midwest factor prices rising. 
Figure 1

Price Convergence for Agriculture

Price Ratios

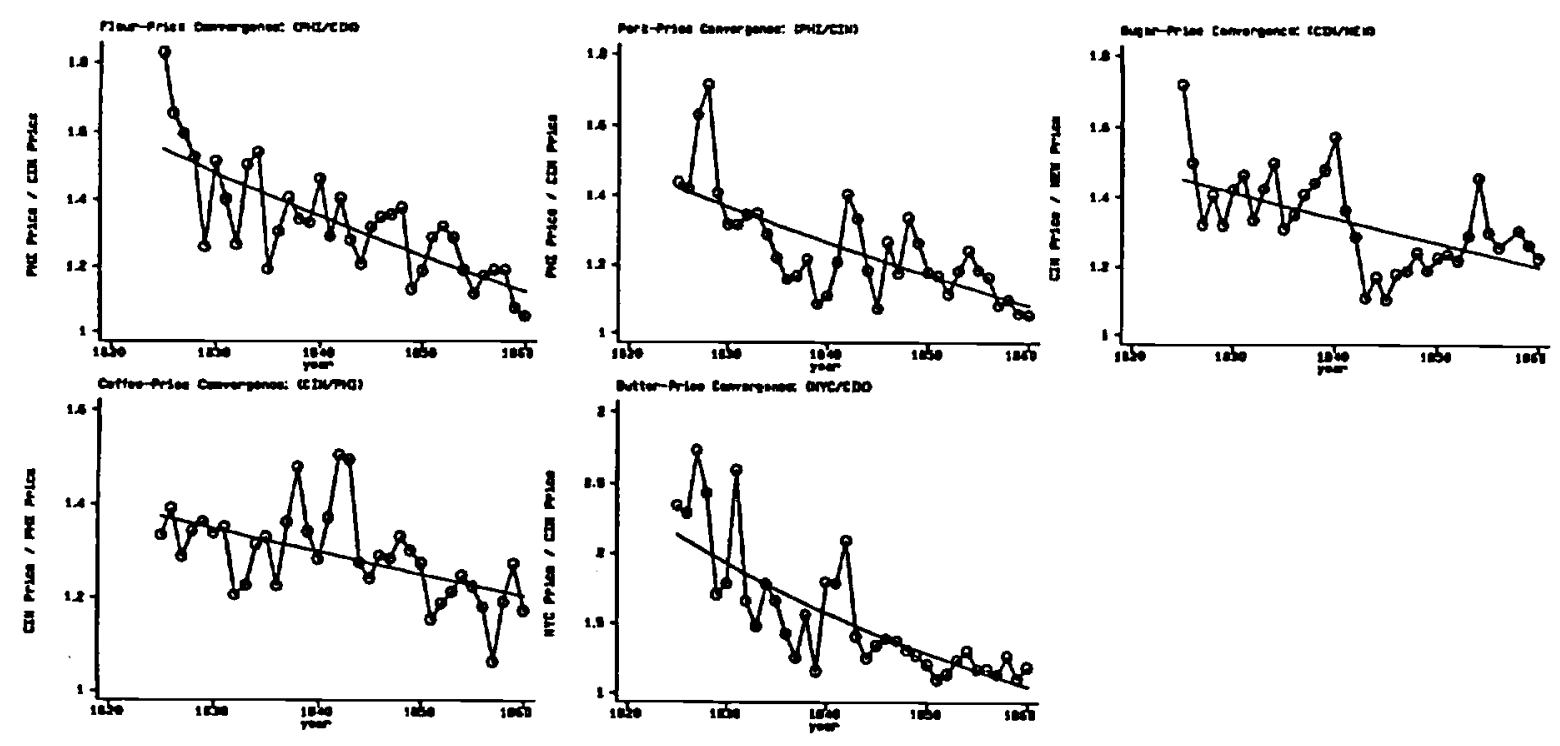

Price Differences
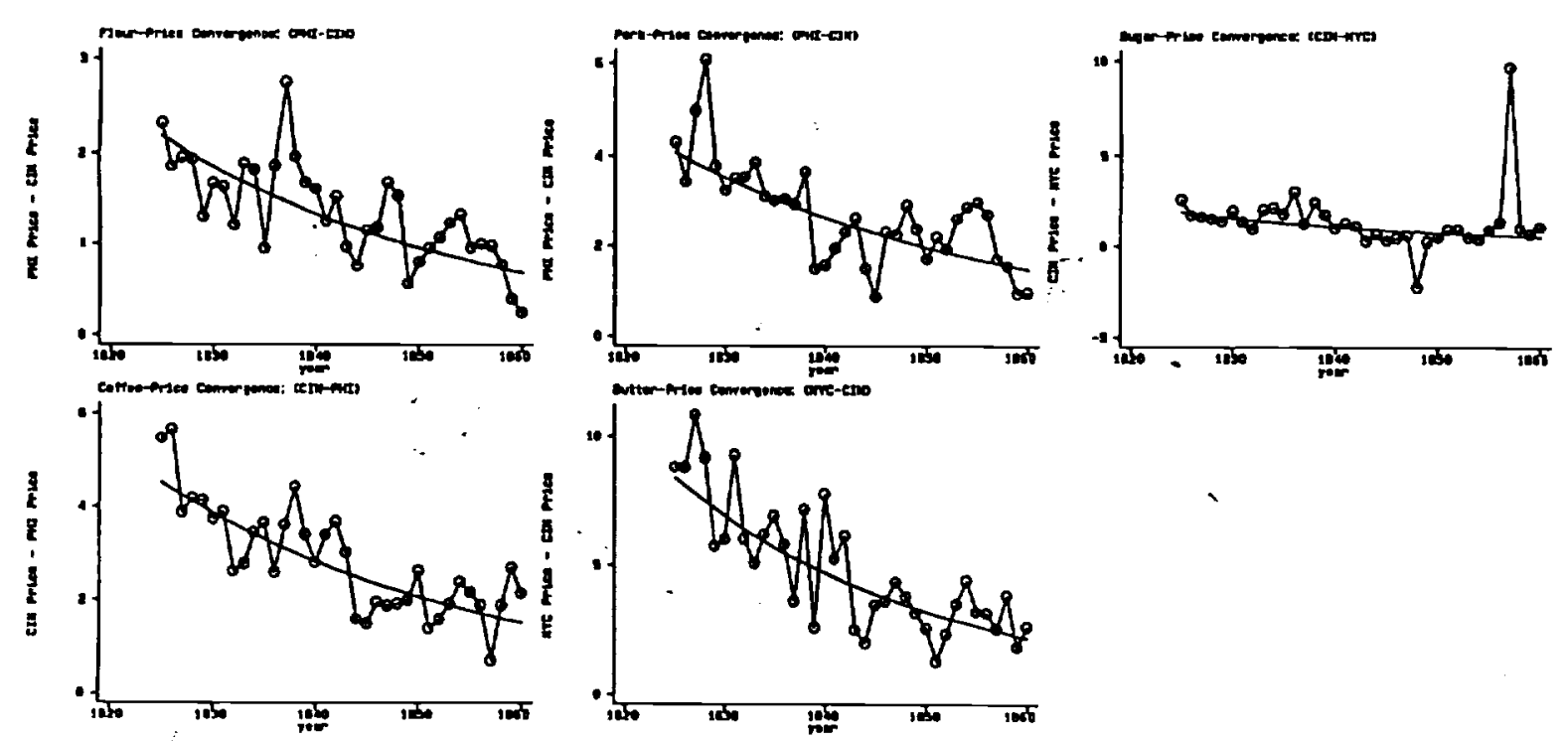

Source: Cole (1938) 
Figure 2

Price Convergence for Manufacturing

Price Ratios

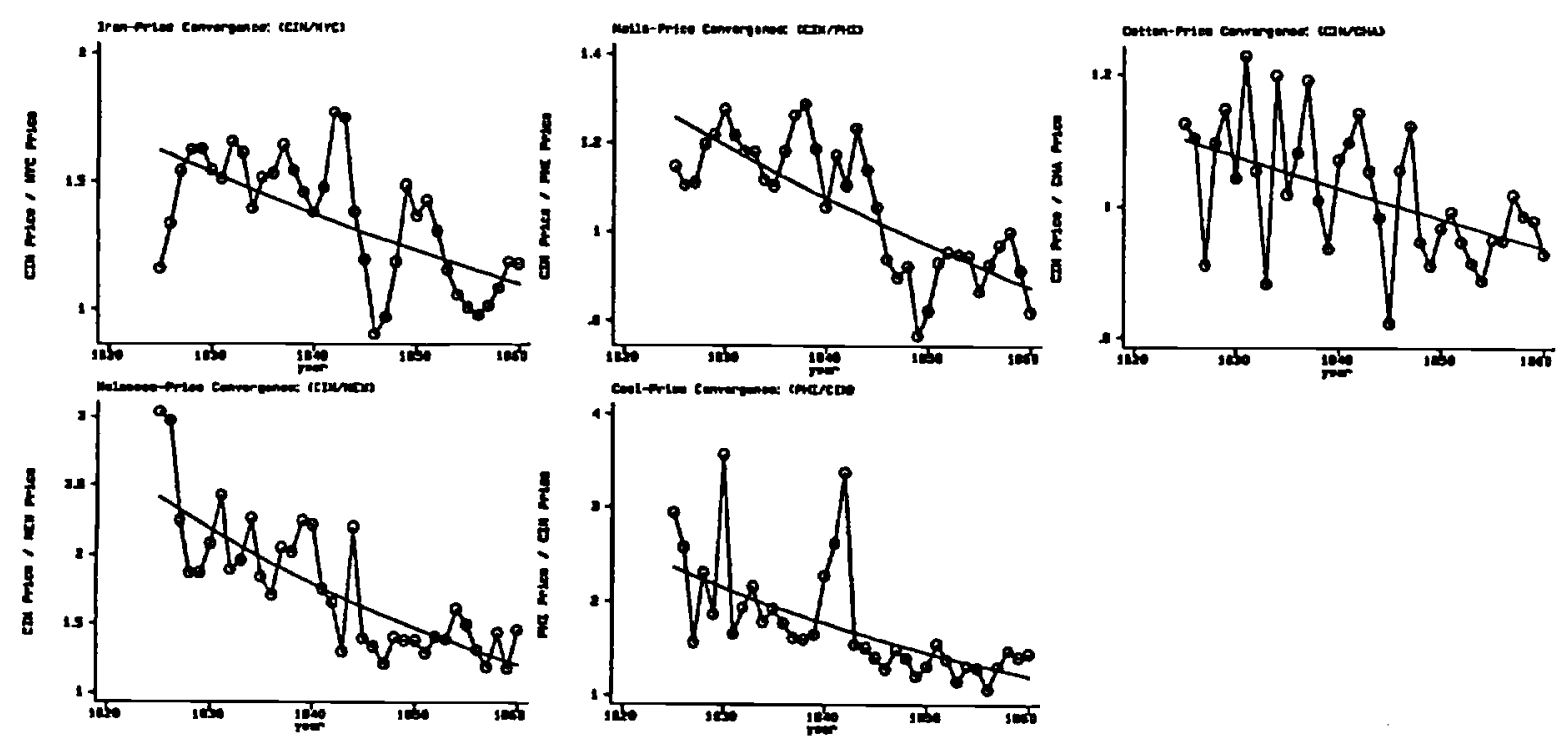

Price Differences

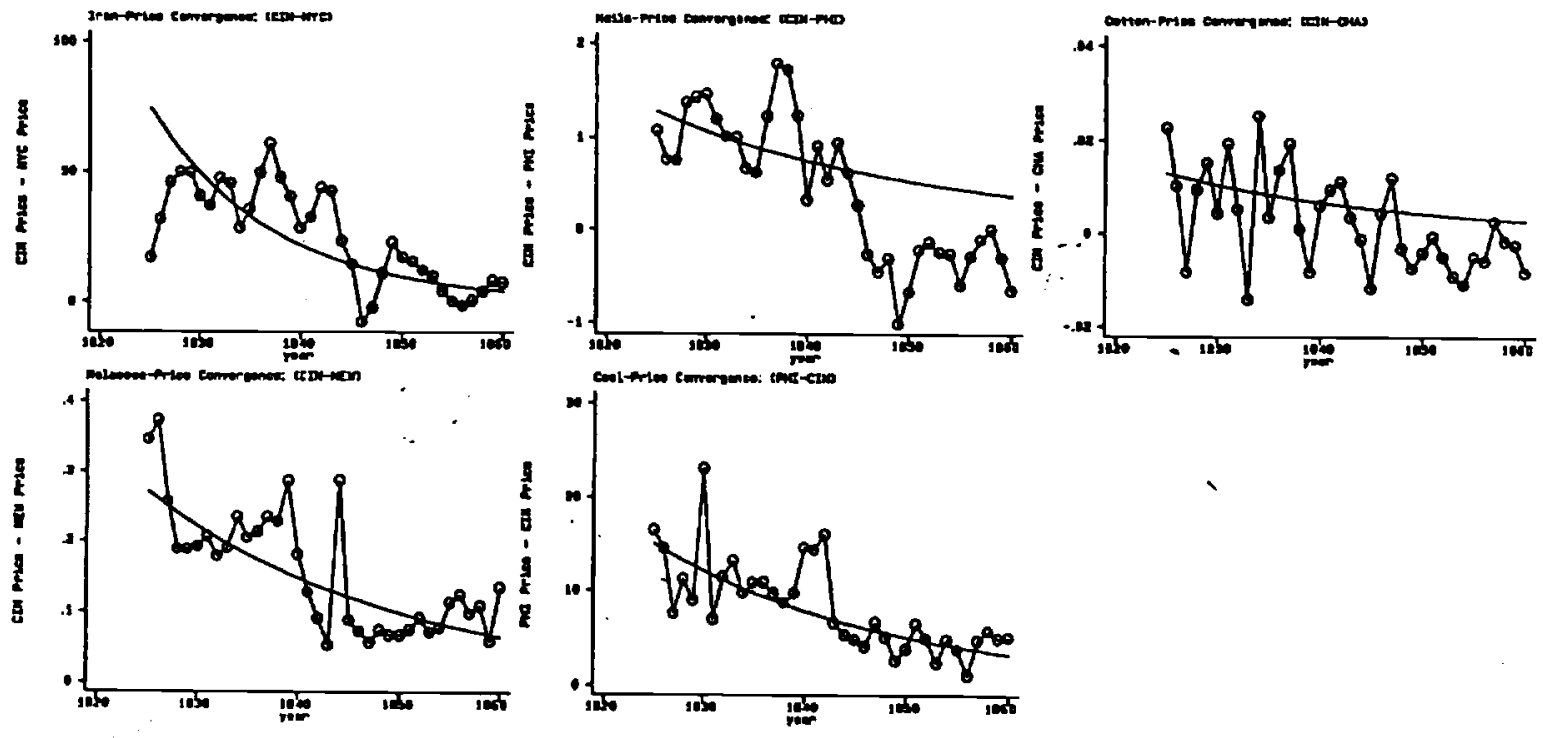

Source: Cole (1938) 
Figure 3

Wage Convergence for Artisans

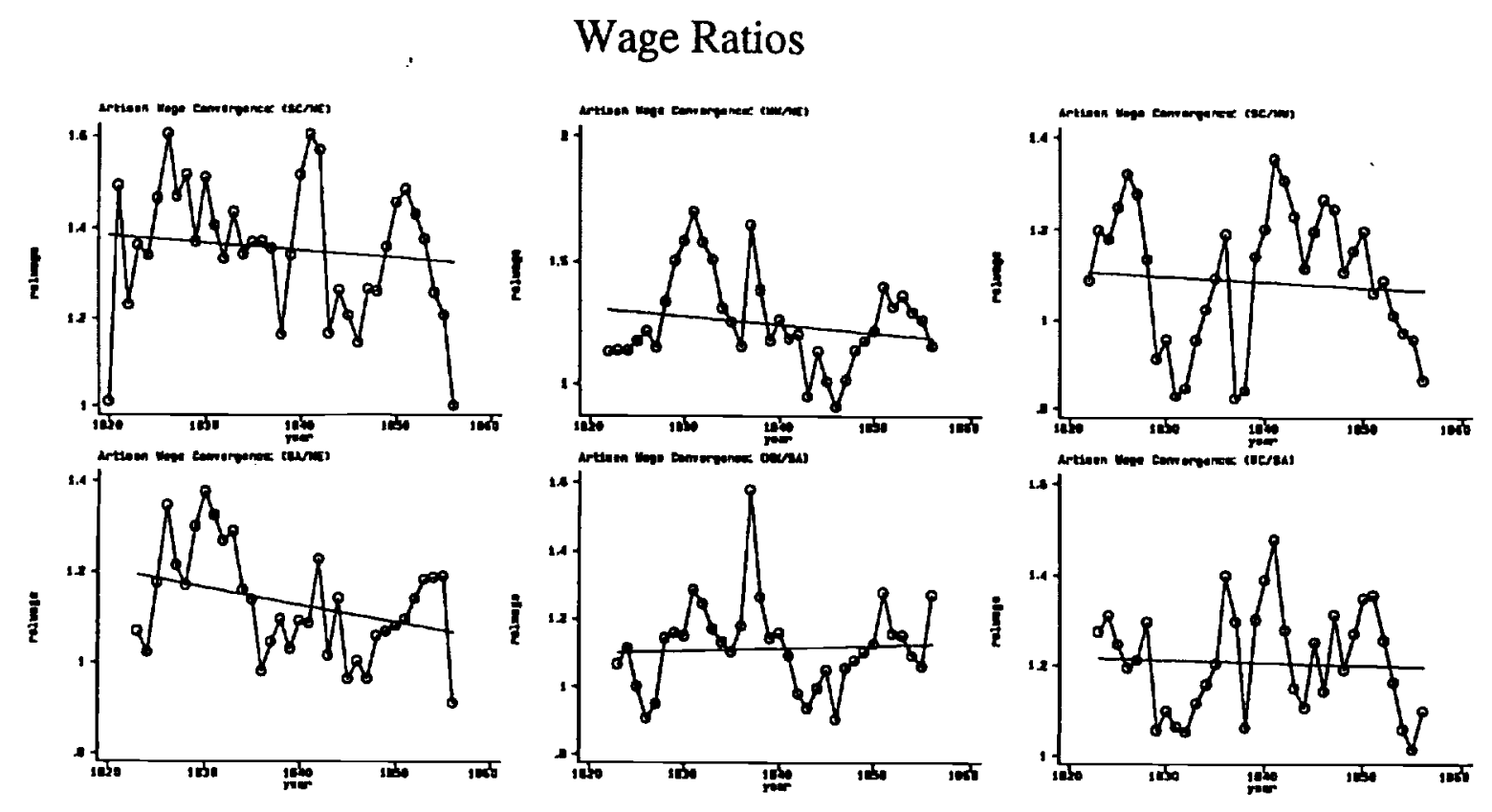

Wage Differences
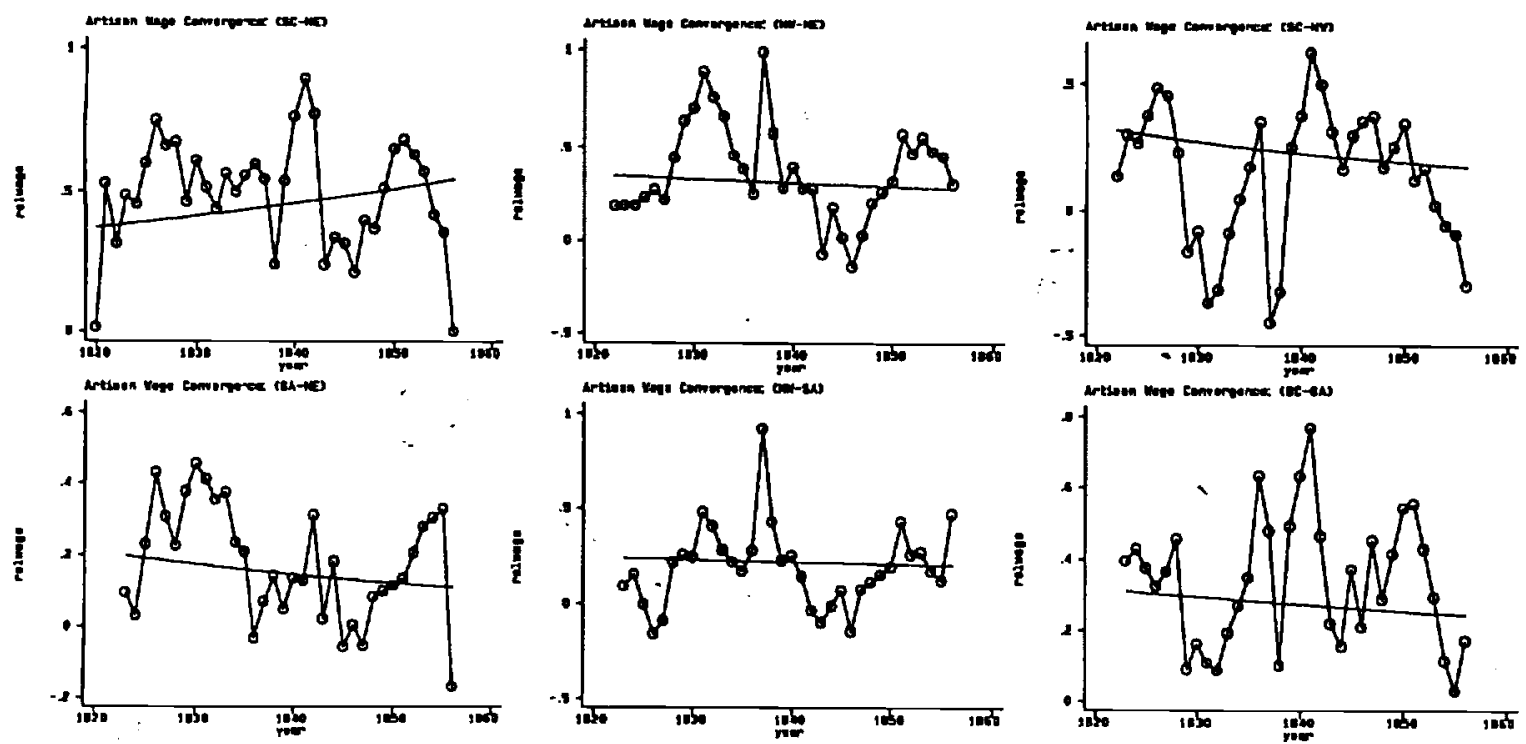

Source: Goldin and Margo (1992) 
Figure 4

Wage Convergence for Clerks

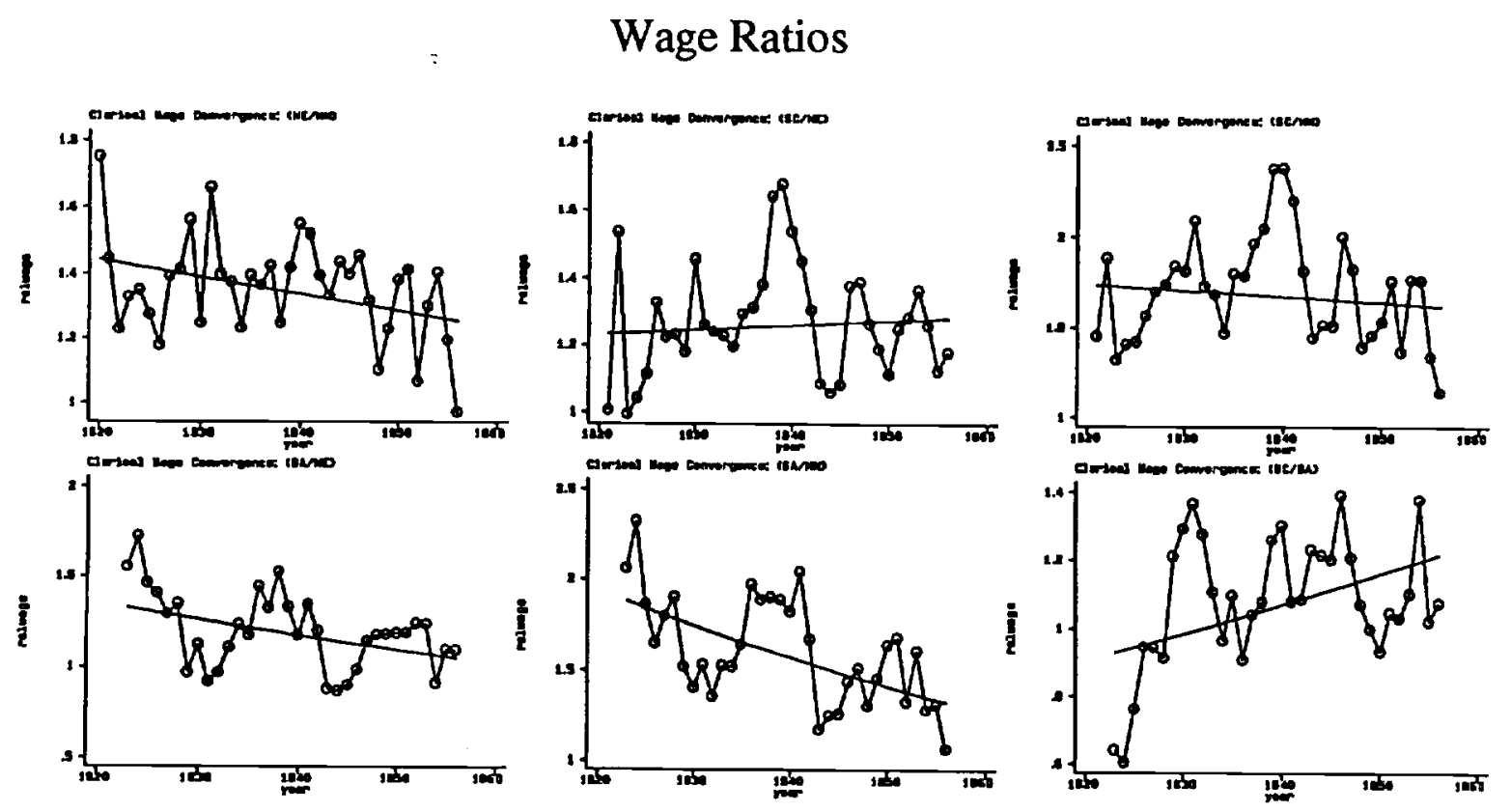

Wage Differences
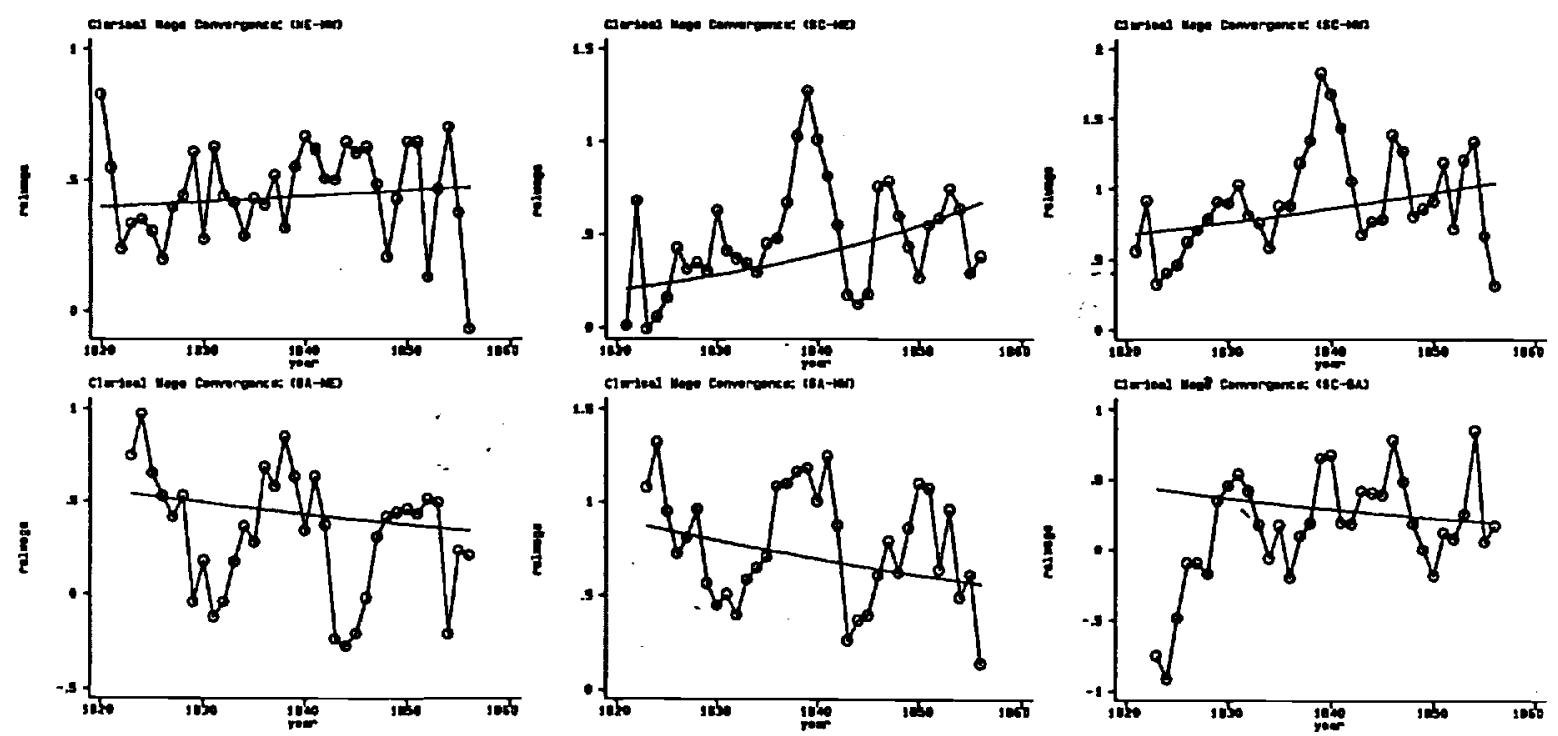

Source: Goldin and Margo (1992) 
Figure 5

Wage Convergence for Laborers

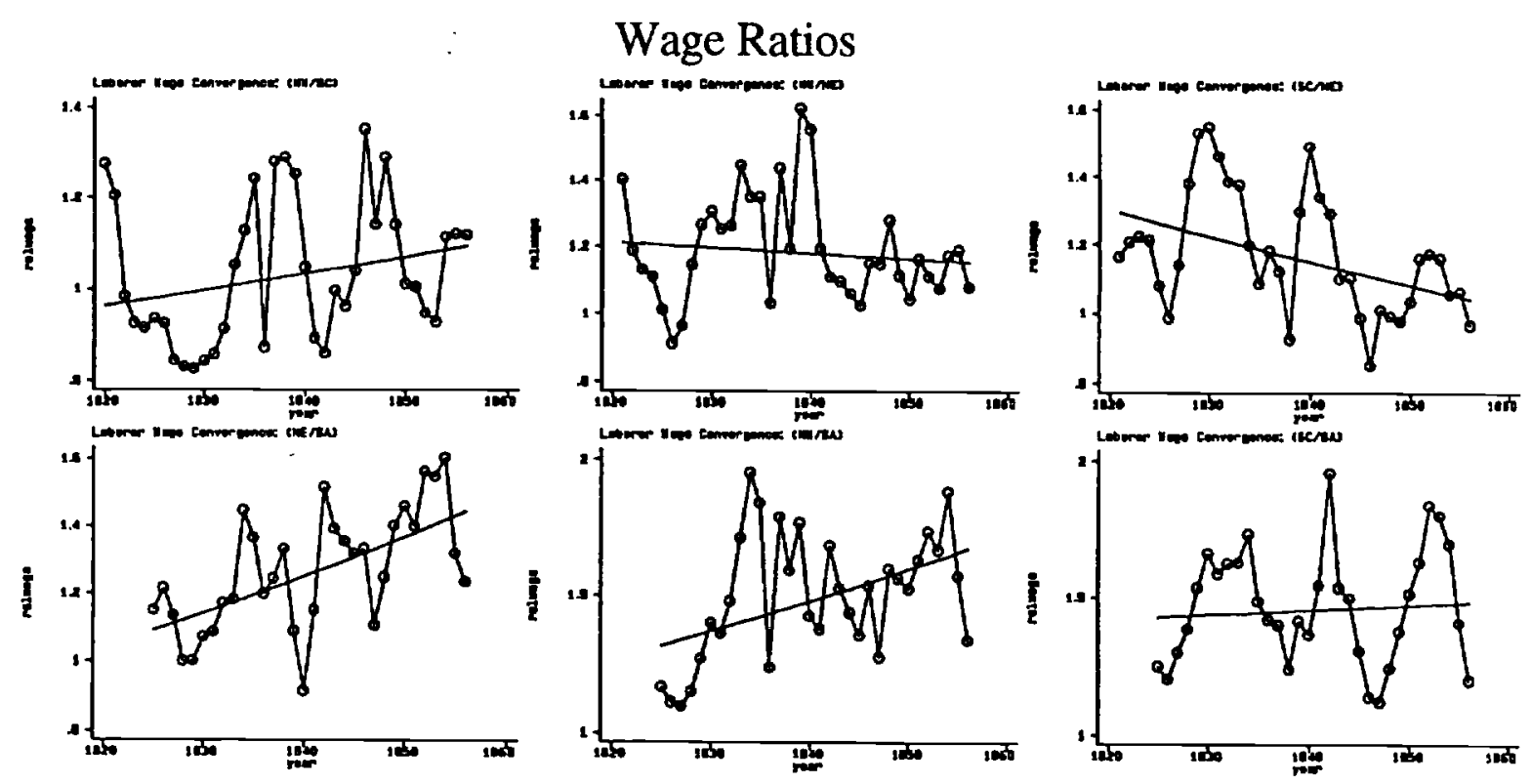

Wage Differences
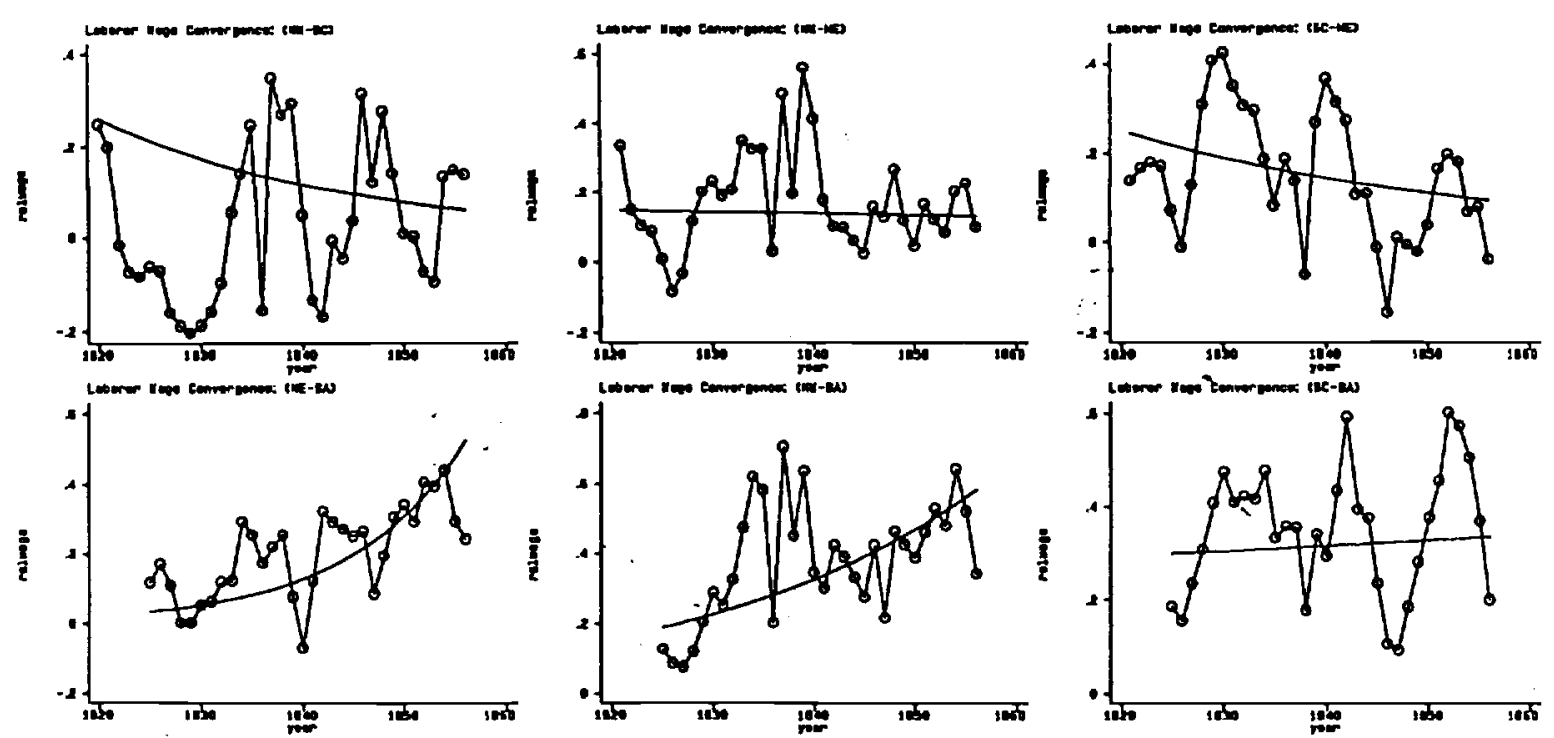

Source: Goldin and Margo (1992) 
Figure 6

Lerner-Pearce Diagram of

Initial Northeast Equilibrium

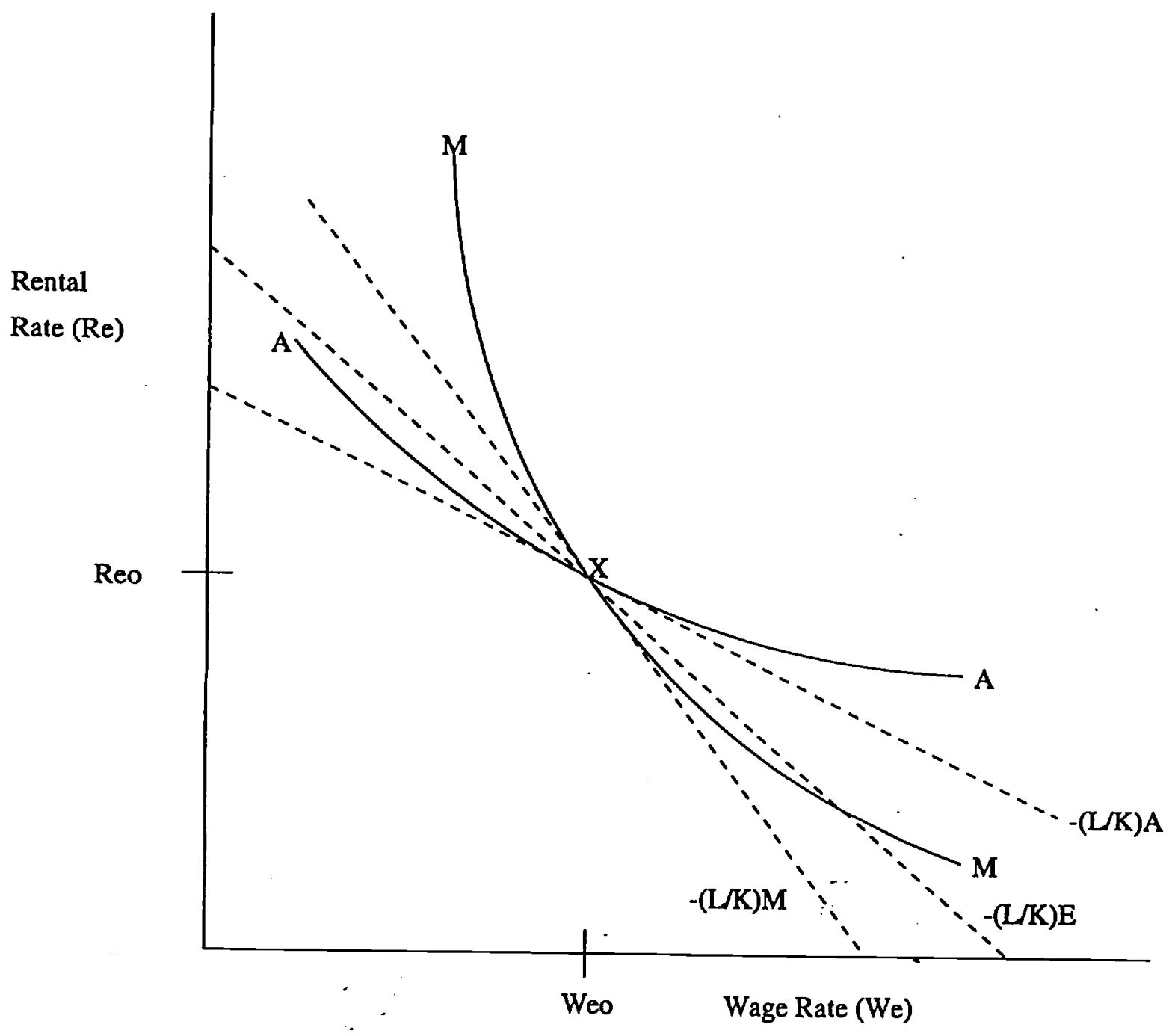

AA is the zero-profit locus for agriculture.

MM is the zero-profit locus for manufacturing.

Because the endowment ray $-(\mathrm{L} / \mathrm{K})_{\mathrm{E}}$ lies within the cone of diversification, the initial equilibrium lies at point $X$. 
Figure 7

Lerner-Pearce Diagram of

Initial Midwest Equilibrium

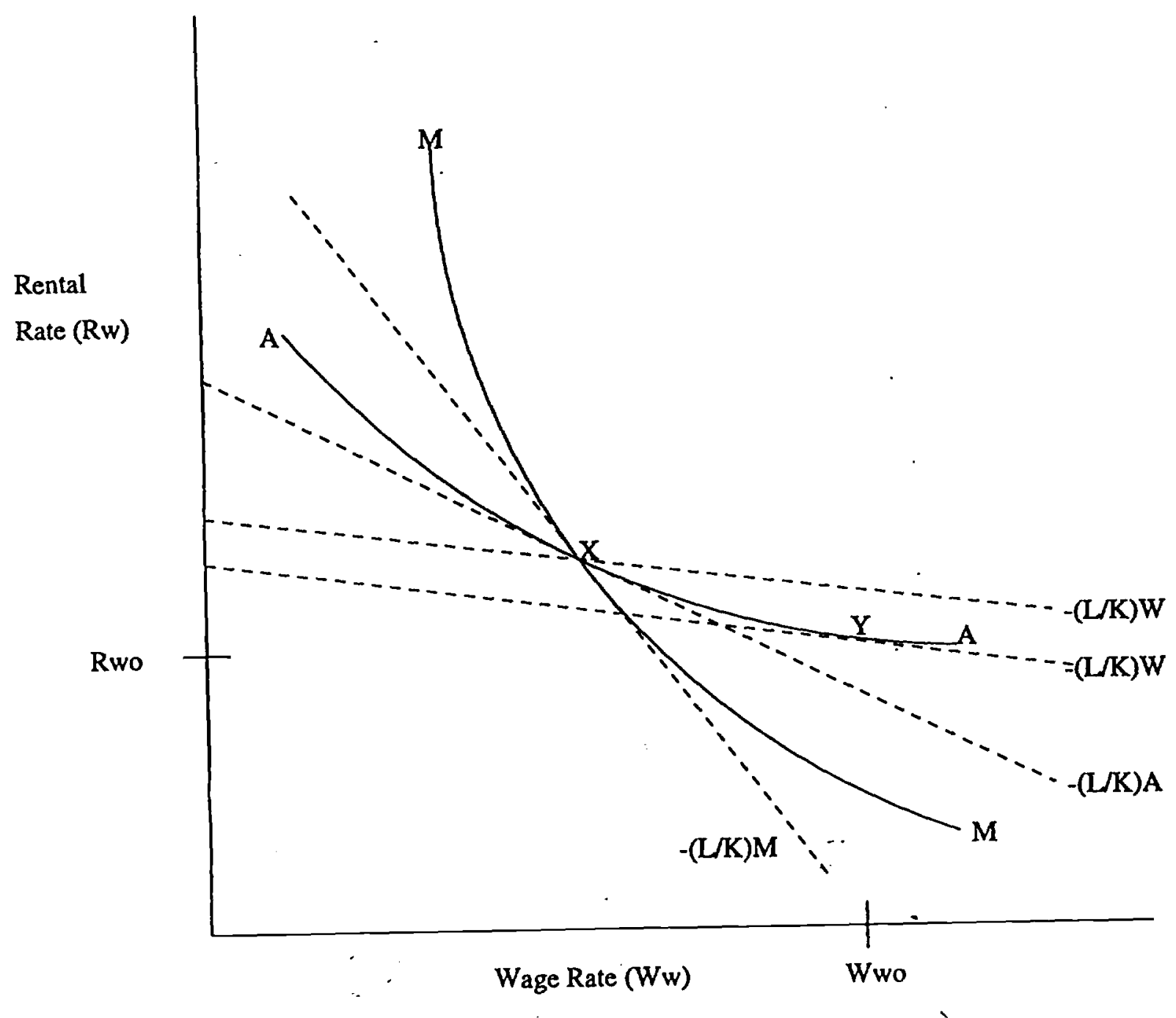

AA is the zero-profit locus for agriculture.

$M M$ is the zero-profit locus for manufacturing.

Because the endowment ray $-(\mathrm{L} / \mathrm{K})_{\mathrm{W}}$ lies outside the cone of diversification, the initial equilibrium lies at point $Y$. 
Figure 8

Lerner-Pearce Diagram of

Final Northeast Equilibrium

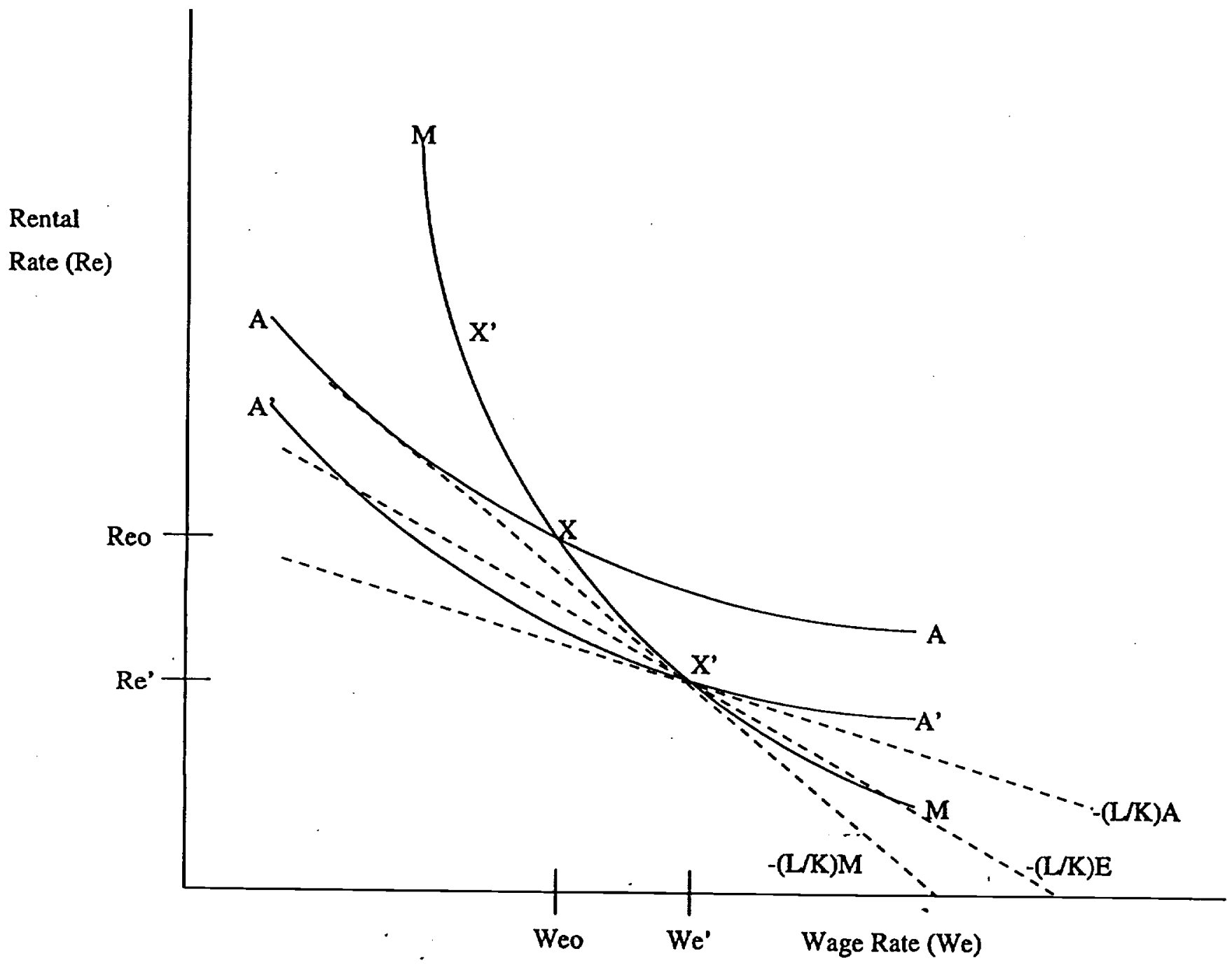

The fall in Northeast agriculture prices shifts the AA locus in to A'A'. The new equilibrium is at point $X^{\prime}$ : the rental rate falls, and the wage rate rises. 
Figure 9

Lerner-Pearce Diagram of

Final Midwest Equilibrium

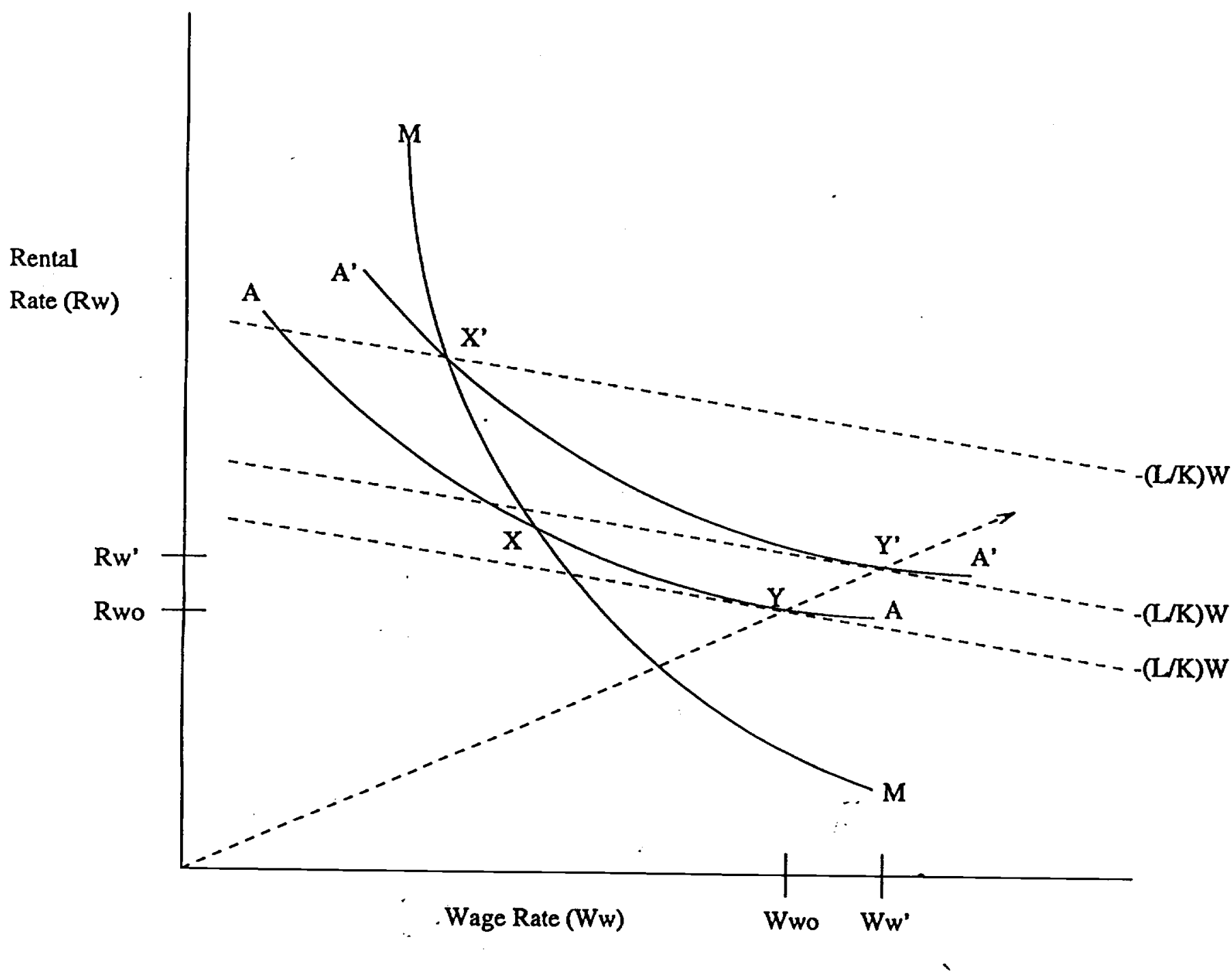

The rise in Midwest agriculture prices shifts the AA locus out to A'A'. The new equilibrium is at point $Y^{\prime}$ : both the rental rate and the wage rate rise. 
Table 1

Expansion of Canals and Railroads

\begin{tabular}{ccc}
\hline \hline Year & Canal Mileage & Railroad Mileage \\
\hline 1820 & 150 & 0 \\
1830 & 1277 & 73 \\
1840 & 3326 & 3328 \\
1850 & 3698 & 8879 \\
1860 & $4000+$ & 30,636 \\
\hline
\end{tabular}

Source: Taylor (1951). 
Table 2

Commodity-Price Convergence

Price Ratios

\begin{tabular}{|c|c|c|c|c|c|}
\hline $\begin{array}{c}\text { Commodity } \\
\text { (units of prices) }\end{array}$ & $\begin{array}{c}\text { Budget } \\
\text { share }\end{array}$ & $\begin{array}{l}\text { Ratio } \\
\text { tracked }\end{array}$ & $\begin{array}{c}\text { Rate of } \\
\text { convergence }\end{array}$ & $\begin{array}{c}\text { Number of } \\
\text { observations }\end{array}$ & 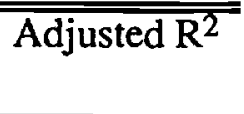 \\
\hline $\begin{array}{l}\text { Butter } \\
(\phi / l b)\end{array}$ & .134 & $\frac{\text { NYC }}{\text { CIN }}$ & $\begin{array}{c}-0.0203^{* * *} \\
(-8.278)\end{array}$ & 36 & .66 \\
\hline $\begin{array}{l}\text { Coffee } \\
(\phi / l \mathrm{~b})\end{array}$ & .073 & $\frac{\mathrm{CIN}}{\mathrm{PHI}}$ & $\begin{array}{c}-0.0037^{* * *} \\
(-3.738)\end{array}$ & 36 & .27 \\
\hline \multirow[t]{2}{*}{$\begin{array}{l}\text { Flour, superfine } \\
\text { (\$/barrel) }\end{array}$} & .146 & $\frac{\text { NYC }}{\text { CIN }}$ & $\begin{array}{c}-0.0096 * * * \\
(-5.737)\end{array}$ & 36 & .48 \\
\hline & & $\frac{\mathrm{PHI}}{\mathrm{CIN}}$ & $\begin{array}{c}-0.0112^{* * *} \\
(-7.814)\end{array}$ & 36 & .61 \\
\hline \multirow[t]{2}{*}{$\begin{array}{l}\text { Pork, mess } \\
\text { (\$/barrel) }\end{array}$} & .045 & $\frac{\text { NYC }}{\text { CIN }}$ & $\begin{array}{c}-0.0099 * * * \\
(-5.837)\end{array}$ & 36 & .49 \\
\hline & & $\frac{\mathrm{PHI}}{\mathrm{CIN}}$ & $\begin{array}{c}-0.0078 * * * \\
(-5.977)\end{array}$ & 36 & .50 \\
\hline \multirow[t]{2}{*}{$\begin{array}{c}\text { Sugar } \\
(\$ / 100 \mathrm{lb})\end{array}$} & .085 & $\frac{\text { CIN }}{\text { NYC }}$ & $\begin{array}{c}-0.0049 * * \\
(-2.644)\end{array}$ & 36 & .15 \\
\hline & & $\frac{\text { CIN }}{\text { NEW }}$ & $\begin{array}{c}-0.0054 * * * \\
(-3.931)\end{array}$ & 36 & .30 \\
\hline $\begin{array}{c}\text { Coal } \\
(ф / \text { bushel) }\end{array}$ & .098 & $\frac{\text { PHI }}{\text { CIN }}$ & $\begin{array}{c}-0.0193^{* * *} \\
(-5.517)\end{array}$ & 36 & .46 \\
\hline \multirow[t]{2}{*}{$\begin{array}{l}\text { Cotton } \\
(\$ / 1 \mathrm{~b})\end{array}$} & .189 & $\frac{\mathrm{CIN}}{\text { NYC }}$ & $\begin{array}{c}-0.0049 * * \\
(-2.732)\end{array}$ & 36 & .05 \\
\hline & & $\frac{\mathrm{CIN}}{\mathrm{CHA}}$ & $\begin{array}{c}-0.0046 * * * \\
(-3.372)\end{array}$ & $\begin{array}{ll} & 36 \\
. & \end{array}$ & .23 \\
\hline $\begin{array}{c}\text { Iron, unspecified } \\
\text { bars } \\
(\$ / \text { ton })\end{array}$ & --- & $\frac{\mathrm{CIN}}{\mathrm{NYC}}$ & $\begin{array}{c}-0.0110^{* * *} \\
(-4.679)\end{array}$ & 36 & .37 \\
\hline $\begin{array}{l}\text { Molasses } \\
\text { (\$/gallon) }\end{array}$ & --- & $\frac{\text { CIN }}{\text { NEW }}$ & $\begin{array}{c}-0.0199 * * * \\
(-8.356)\end{array}$ & 36 & .66 \\
\hline \multirow[t]{2}{*}{$\begin{array}{l}\text { Nails, cut } \\
\quad(\phi / \mathrm{b})\end{array}$} & -..- & $\frac{\text { CIN }}{\text { NYC }}$ & $\begin{array}{c}-0.0084^{* * * *} \\
(-4.332)\end{array}$ & 36 & .34 \\
\hline & & $\frac{\text { CIN }}{\mathrm{PHI}}$ & $\begin{array}{c}-0.0103^{* * *} \\
(-7.049)\end{array}$ & 36 & .58 \\
\hline
\end{tabular}


Table 2

Commodity-Price Convergence

Price Ratios

(continued)

\begin{tabular}{|c|c|c|c|c|c|}
\hline $\begin{array}{l}\text { Commodity } \\
\text { (units) }\end{array}$ & $\begin{array}{c}\overline{\text { Budget }} \\
\text { share }\end{array}$ & $\begin{array}{c}\text { Ratio } \\
\text { tracked }\end{array}$ & $\begin{array}{c}\text { Rate of } \\
\text { convergence }\end{array}$ & $\begin{array}{c}\text { Number of } \\
\text { observations }\end{array}$ & Adjusted $\mathrm{R}^{2}$ \\
\hline $\begin{array}{c}\text { All goods } \\
1820-1860\end{array}$ & ---- & ---- & $\begin{array}{c}-0.0097^{* * *} \\
(-18.851)\end{array}$ & 605 & .38 \\
\hline $\begin{array}{l}\text { All goods, no } \\
\text { doubles } \\
1820-1860\end{array}$ & $-\cdots-$ & $\cdots$ & $\begin{array}{c}-0.0107 * * * \\
(-15.564)\end{array}$ & 400 & .38 \\
\hline $\begin{array}{l}\text { All goods } \\
1825-1860\end{array}$ & -..- & $-\cdots$ & $\begin{array}{c}-0.0095 * * * \\
(-16.702)\end{array}$ & 540 & .35 \\
\hline $\begin{array}{c}\text { All goods, no } \\
\text { doubles } \\
1825-1860\end{array}$ & --- & --- & $\begin{array}{c}-0.0107 * * * \\
(-13.915)\end{array}$ & 360 & .36 \\
\hline
\end{tabular}

* = Significant at the 5 percent level.

** = Significant at the 1 percent level.

$* * *=$ Significant at the 0.5 percent level.

Notes: The rates of convergence for each price ratio are the estimates of $\beta$ from the regression $\ln \left(\frac{P_{B}}{P_{A}}\right) i t=\alpha_{i}+\beta t+\varepsilon_{i t}$. "All goods" refers to the fixed-effects specification of the panel of all price-ratio series pooled together. "All goods, no doubles" is a similar panel but with only one price-ratio series per commodity. CHA is Charleston, CIN is Cincinnati, NEW is New Orleans, NYC is New York, and PHI is Philadelphia. The figures in parentheses are t-statistics.

Source: Cole (1938). See text for a detailed description. 
Table 3

Commodity-Price Convergence

Price Differences

\begin{tabular}{|c|c|c|c|c|c|}
\hline $\begin{array}{l}\text { Commodity } \\
\text { (units of prices) }\end{array}$ & $\begin{array}{c}\text { Budget } \\
\text { share }\end{array}$ & $\begin{array}{c}\text { Difference } \\
\text { tracked }\end{array}$ & $\begin{array}{c}\text { Rate of } \\
\text { convergence }\end{array}$ & $\begin{array}{c}\text { Number of } \\
\text { observations }\end{array}$ & $\overline{\text { Adjusted } \mathrm{R}^{\mathbf{2}}}$ \\
\hline $\begin{array}{l}\text { Butter } \\
(\phi / l b)\end{array}$ & .134 & NYC - CIN & $\begin{array}{c}-0.0382 * * * \\
(-7.111)\end{array}$ & 36 & .59 \\
\hline $\begin{array}{l}\text { Coffee } \\
(\notin / \mathrm{lb})\end{array}$ & .073 & CIN - PHI & $\begin{array}{c}-0.0311 * * * \\
(-6.769)\end{array}$ & 36 & .56 \\
\hline \multirow[t]{2}{*}{$\begin{array}{l}\text { Flour, superfine } \\
\text { (\$/barrel) }\end{array}$} & .146 & NYC - CIN & $\begin{array}{c}-0.0474 * * * \\
(-3.824)\end{array}$ & 35 & .29 \\
\hline & & PHI - CIN & $\begin{array}{c}-0.0333 * * * \\
(-5.919)\end{array}$ & 36 & .49 \\
\hline \multirow[t]{2}{*}{$\begin{array}{l}\text { Pork, mess } \\
\text { (\$/barrel) }\end{array}$} & .045 & NYC - CIN & $\begin{array}{c}-0.0525 * * * \\
(-6.622)\end{array}$ & 35 & .56 \\
\hline & & PHI - CIN & $\begin{array}{c}-0.0293 * * * \\
(-5.426)\end{array}$ & 36 & .45 \\
\hline \multirow[t]{2}{*}{$\begin{array}{c}\text { Sugar } \\
(\$ / 100 \mathrm{lb})\end{array}$} & .085 & CIN - NYC & $\begin{array}{c}-0.0392 * * * \\
(-4.069)\end{array}$ & 34 & .32 \\
\hline & & CIN - NEW & $\begin{array}{c}-0.0305^{* * *} \\
(-4.449)\end{array}$ & 35 & .36 \\
\hline $\begin{array}{c}\text { Coal } \\
\text { ( } \notin / \text { bushel) }\end{array}$ & .098 & PHI - CIN & $\begin{array}{c}-0.0431 * * * \\
(-6.262)\end{array}$ & 36 & .52 \\
\hline \multirow[t]{2}{*}{$\begin{array}{l}\text { Cotton } \\
(\$ / 1 b)\end{array}$} & .189 & CIN - NYC & $\begin{array}{c}-0.0950 * * * \\
(-5.200)\end{array}$ & 19 & .72 \\
\hline & & CIN - CHA & $\begin{array}{l}-0.0448 \\
(-1.878)\end{array}$ & 11 & .12 \\
\hline $\begin{array}{c}\text { Iron, unspecified } \\
\text { bars } \\
(\$ / \text { ton })\end{array}$ & $-\cdots$ & CIN - NYC & $\begin{array}{c}-0.0819 * * * \\
(-5.729)\end{array}$ & 33 & .50 \\
\hline $\begin{array}{l}\text { Molasses } \\
\text { (\$/gallon) }\end{array}$ & ---- & CIN - NEW & $\begin{array}{c}-0.0408 * * * \\
(-6.221)\end{array}$ & 35 & .52 \\
\hline \multirow[t]{2}{*}{$\begin{array}{l}\text { Nails, cut } \\
\qquad(\notin / \mathrm{lb})\end{array}$} & --- & $\mathrm{CIN}-\mathrm{NYC}$ & $\begin{array}{l}-0.0154 \\
(-1.192)\end{array}$ & 20 & .02 \\
\hline & & CIN - PHI & $\begin{array}{l}-0.0359 * \\
(-2.112)\end{array}$ & 21 & .14 \\
\hline
\end{tabular}

See bottom of next page for explanatory notes. 
Table 3

Commodity-Price Convergence

Price Differences

(continued)

\begin{tabular}{|c|c|c|c|c|c|}
\hline $\begin{array}{l}\text { Commodity } \\
\text { (units) }\end{array}$ & $\begin{array}{c}\text { Budget } \\
\text { share }\end{array}$ & $\begin{array}{c}\text { Difference } \\
\text { tracked }\end{array}$ & $\begin{array}{c}\text { Rate of } \\
\text { convergence }\end{array}$ & $\begin{array}{l}\text { Number of } \\
\text { observations }\end{array}$ & Adjusted $\mathrm{R}^{2}$ \\
\hline $\begin{array}{l}\text { All goods } \\
1820-1860\end{array}$ & $\cdots$ & $\ldots$ & $\begin{array}{c}-0.0424 * * * \\
(-18.325)\end{array}$ & 520 & .40 \\
\hline $\begin{array}{l}\text { All goods, no } \\
\text { doubles } \\
1820-1860\end{array}$ & --- & $-\cdots$ & $\begin{array}{c}-0.0461 * * * \\
(-16.246)\end{array}$ & 350 & .44 \\
\hline $\begin{array}{l}\text { All goods } \\
1825-1860\end{array}$ & $\ldots$ & $\ldots$ & $\begin{array}{c}-0.0410 * * * \\
(-15.715)\end{array}$ & 461 & .36 \\
\hline $\begin{array}{l}\text { All goods, no } \\
\text { doubles } \\
1825-1860\end{array}$ & -- & $\ldots$ & $\begin{array}{c}-0.0456 * * * \\
(-14.125)\end{array}$ & 313 & .40 \\
\hline
\end{tabular}

$*=$ Significant at the 5 percent level.

** = Significant at the 1 percent level.

$* * *$ = Significant at the 0.5 percent level.

Notes: The rates of convergence for each price ratio are the estimates of $\beta$ from the regression $\ln \left(P_{B}-P_{A}\right) i t=\alpha_{i}+\beta t+\varepsilon_{i t}$. "All goods" refers to the fixed-effects specification of the panel of all price-ratio series pooled together. "All goods, no doubles" is a similar panel but with only one price-ratio series per commodity. CHA is Charleston, CIN is Cincinnati, NEW is New Orleans, NYC is New York, and PHI is Philadelphia. The figures in parentheses are t-statistics.

Source: Cole (1938). See text for a detailed description. 
Table 4

Factor-Price Convergence

Wage Ratios

\begin{tabular}{|c|c|c|c|c|c|c|c|c|c|}
\hline Factor & $\begin{array}{l}\text { Wage } \\
\text { Ratio }\end{array}$ & $\begin{array}{c}\text { Rate of } \\
\text { convergence }\end{array}$ & $\begin{array}{c}\text { Number } \\
\text { Obs. }\end{array}$ & $\begin{array}{l}\text { Adj. } \\
\mathrm{R}^{2}\end{array}$ & Factor & $\begin{array}{l}\text { Wage } \\
\text { Ratio }\end{array}$ & $\begin{array}{c}\text { Rate of } \\
\text { convergence }\end{array}$ & $\begin{array}{l}\text { Number } \\
\text { Obs. }\end{array}$ & $\begin{array}{l}\text { Adj. } \\
\mathrm{R}^{2}\end{array}$ \\
\hline Artisan & $\frac{\mathrm{SC}}{\mathrm{NE}}$ & $\begin{array}{l}-0.0012 \\
(-0.715)\end{array}$ & 36 & -.01 & Laborer & $\frac{\mathrm{MW}}{\mathrm{SC}}$ & $\begin{array}{l}0.0035 \\
(1.555)\end{array}$ & 37 & .04 \\
\hline -.-- & $\frac{\mathrm{MW}}{\mathrm{NE}}$ & $\begin{array}{l}-0.0027 \\
(-1.115)\end{array}$ & 35 & .01 & ----. & $\frac{\mathrm{MW}}{\mathrm{NE}}$ & $\begin{array}{l}-0.0013 \\
(-0.625)\end{array}$ & 36 & -.02 \\
\hline ---- & $\frac{\mathrm{SC}}{\mathrm{MW}}$ & $\begin{array}{l}-0.0011 \\
(-0.445)\end{array}$ & 35 & -.02 & --.-- & $\frac{\mathrm{SC}}{\mathrm{NE}}$ & $\begin{array}{c}-0.0061^{* *} \\
(-2.832)\end{array}$ & 36 & .17 \\
\hline --.-- & $\frac{S A}{N E}$ & $\begin{array}{c}-0.0034 * \\
(-1.988)\end{array}$ & 33 & .08 & ---- & $\frac{\mathrm{NE}}{\mathrm{SA}}$ & $\begin{array}{c}0.0090^{* * *} \\
(4.143)\end{array}$ & 32 & .34 \\
\hline ----- & $\frac{\mathrm{MW}}{\mathrm{SA}}$ & $\begin{array}{l}0.0007 \\
(0.348)\end{array}$ & 34 & -.03 & ----- & $\frac{\mathrm{MW}}{\mathrm{SA}}$ & $\begin{array}{c}0.0077 * * \\
(2.841)\end{array}$ & 32 & .19 \\
\hline ----- & $\frac{S C}{S A}$ & $\begin{array}{l}-0.0005 \\
(-0.286)\end{array}$ & 34 & -.03 & -.-- & $\frac{\mathrm{SC}}{\mathrm{SA}}$ & $\begin{array}{l}0.0012 \\
(0.422)\end{array}$ & 32 & -.02 \\
\hline Clerk & $\frac{\mathrm{NE}}{\mathrm{MW}}$ & $\begin{array}{c}-0.0039 * \\
(-2.368)\end{array}$ & 36 & .11 & & & & & \\
\hline -..-- & $\frac{\mathrm{SC}}{\mathrm{NE}}$ & $\begin{array}{l}0.0011 \\
(0.518)\end{array}$ & 36 & -.02 & & & & & \\
\hline --.-- & $\frac{\mathrm{SC}}{\mathrm{MW}}$ & $\begin{array}{l}-0.0019 \\
(-0.703)\end{array}$ & 36 & -.01 & & & & & \\
\hline ---- & $\frac{S A}{N E}$ & $\begin{array}{c}-0.0070 * \\
(-2.517)\end{array}$ & 34 & .14 & & & & & \\
\hline ----- & $\frac{\mathrm{SA}}{\mathrm{MW}}$ & $\begin{array}{c}-0.0106 * * * \\
(-4.027)\end{array}$ & 34 & .32 & All & ---- & $\begin{array}{l}-0.0008 \\
(-1.477)\end{array}$ & 625 & .01 \\
\hline ---- & $\frac{S C}{S A}$ & $\begin{array}{c}0.0081^{* *} \\
(2.610)\end{array}$ & 34 & .15 & $\begin{array}{c}\text { All with } \\
\beta<0\end{array}$ & ---- & $\begin{array}{c}-0.0034 * * * \\
(-5.252)\end{array}$ & 422 & .06 \\
\hline
\end{tabular}

* = Significant at the 5 percent level.

$* *=$ Significant at the 1 percent level.

$* * *=$ Significant at the 0.5 percent level.

Notes: The rates of convergence for each wage ratio are the estimates of $\beta$ from the regression $\ln \left(\frac{W_{B}}{W A}\right)_{i t}=\alpha_{i}+\beta t+\varepsilon_{i t}$. "All" refers to the fixed-effects specification of the panel of all wageratio series pooled together. "All with $\beta<0$ " is a similar panel but with only those individual series which displayed convergence. MW is Midwest, NE is Northeast, SA is South Atlantic, and SC is South Central. The figures in parentheses are t-statistics.

Source: Goldin and Margo (1992). See text for a detailed description. 
Table 5

Factor-Price Convergence

Wage Differences

\begin{tabular}{|c|c|c|c|c|c|c|c|c|c|}
\hline Factor & $\begin{array}{c}\text { Wage } \\
\text { Diff }\end{array}$ & $\begin{array}{c}\text { Rate of } \\
\text { convergence }\end{array}$ & $\begin{array}{c}\text { Number } \\
\text { Obs. }\end{array}$ & $\begin{array}{l}\text { Adj. } \\
R^{2}\end{array}$ & $\overline{\text { Factor }}$ & $\begin{array}{l}\text { Wage } \\
\text { Diff }\end{array}$ & $\begin{array}{l}\text { Rate of } \\
\text { convergence }\end{array}$ & $\begin{array}{l}\text { Number } \\
\text { Obs. }\end{array}$ & $\begin{array}{l}\text { Adj. } \\
R^{2}\end{array}$ \\
\hline Artisan & SC-NE & $\begin{array}{l}0.0105 \\
(0.974)\end{array}$ & 36 & -.00 & Laborer & MW-SC & $\begin{array}{l}-0.0401 \\
(-1.400)\end{array}$ & $\overline{19}$ & .04 \\
\hline 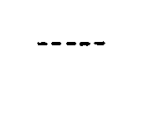 & MW-NE & $\begin{array}{l}-0.0062 \\
(-0.415)\end{array}$ & 33 & -.03 & $\ldots$ & MW-NE & $\begin{array}{l}-0.0032 \\
(-0.215)\end{array}$ & 34 & -.03 \\
\hline --.- & SC-MW & $\begin{array}{l}-0.0180 \\
(-1.198)\end{array}$ & 25 & .02 & $\ldots$ & SC-NE & $\begin{array}{c}-0.0279 * \\
(-1.982)\end{array}$ & 29 & .09 \\
\hline$-\cdots-$ & SA-NE & $\begin{array}{l}-0.0174 \\
(-0.878)\end{array}$ & 30 & -.01 & 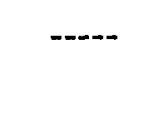 & NE-SA & $\begin{array}{c}0.0889 * * * \\
(3.368)\end{array}$ & 31 & .26 \\
\hline --.- & MW-SA & $\begin{array}{l}-0.0046 \\
(-0.391)\end{array}$ & 27 & -.03 & -.--- & MW-SA & $\begin{array}{c}0.0366^{* * *} \\
(4.054)\end{array}$ & 32 & .33 \\
\hline$-\cdots-$ & SC-SA & $\begin{array}{l}-0.0074 \\
(-0.574)\end{array}$ & 34 & -.02 & -..-. & SC-SA & $\begin{array}{l}0.0036 \\
(0.390)\end{array}$ & 32 & -.03 \\
\hline Clerk & NE-MW & $\begin{array}{l}0.0050 \\
(0.751)\end{array}$ & 36 & -.01 & & & & & \\
\hline$\cdots$ & SC-NE & $\begin{array}{c}0.0336^{*} \\
(2.332)\end{array}$ & 35 & .11 & & & & & \\
\hline -..-- & SC-MW & $\begin{array}{l}0.0122 \\
(1.878)\end{array}$ & 36 & .07 & & & & & \\
\hline -...- & SA-NE & $\begin{array}{l}-0.0137 \\
(-1.610)\end{array}$ & 26 & .06 & & & & & \\
\hline -.-.- & SA-MW & $\begin{array}{l}-0.0134 \\
(-1.592)\end{array}$ & 34 & .04 & All & -.-- & $\begin{array}{l}-0.0080 \\
(-1.341)\end{array}$ & 577 & .01 \\
\hline -..-- & SC-SA & $\begin{array}{l}-0.0240 \\
(-1.302)\end{array}$ & 24 & .03 & $\begin{array}{c}\text { All with } \\
\beta<0\end{array}$ & --.- & $\begin{array}{c}-0.0227 * * * \\
(-5.097)\end{array}$ & 325 & .08 \\
\hline \multicolumn{10}{|c|}{$\begin{array}{l}*=\text { Significant at the } 5 \text { percent level. } \\
* *=\text { Significant at the } 1 \text { percent level. } \\
* * *=\text { Significant at the } 0.5 \text { percent level. }\end{array}$} \\
\hline \multicolumn{10}{|c|}{$\begin{array}{l}\text { Notes: The rates of convergence for each wage ratio are the estimates of } \beta \text { from thè regression } \\
\ln \left(\frac{W_{B}}{W_{A}}\right) \text { it }=\alpha_{i}+\beta t+\varepsilon_{i t} \text {. "All" refers to the fixed-effects specification of the panel of all wage- } \\
\text { ratio series pooled together. "All with } \beta<0 " \text { is a similar panel but with only those individual series } \\
\text { which displayed convergence. MW is Midwest, NE is Northeast, SA is South Atlantic, and SC is } \\
\text { South Central. The figures in parentheses are t-statistics. } \\
\text { Source: Goldin and Margo (1992). See text for a detailed description. }\end{array}$} \\
\hline
\end{tabular}


Table 6

States in the Midwest

Reporting Zero Manufacturing Production

\begin{tabular}{|c|c|c|c|c|c|}
\hline $\begin{array}{l}\text { Manufacturing } \\
\text { product }\end{array}$ & $\begin{array}{l}\text { Zero output, } \\
1850\end{array}$ & $\begin{array}{l}\text { Zero output, } \\
1860\end{array}$ & $\begin{array}{l}\text { Manufacturing } \\
\text { product }\end{array}$ & $\begin{array}{c}\text { Zero output, } \\
1850\end{array}$ & $\begin{array}{l}\text { Zero output, } \\
1860\end{array}$ \\
\hline $\begin{array}{l}\text { Cotton } \\
\text { goods }\end{array}$ & $\begin{array}{l}\text { IA, IL, KS, } \\
\text { MI, MN, WI }\end{array}$ & $\begin{array}{c}\text { IA, KS, } \\
\text { MI, MN, WI }\end{array}$ & $\begin{array}{l}\text { Rubber } \\
\text { goods }\end{array}$ & All & All \\
\hline $\begin{array}{l}\text { Woolen } \\
\text { goods }\end{array}$ & $\mathrm{KS}, \mathrm{MN}, \mathrm{WI}$ & $\mathrm{MN}, \mathrm{KS}$ & $\begin{array}{l}\text { Jewelry \& } \\
\text { silverware }\end{array}$ & All & All \\
\hline $\begin{array}{l}\text { Boots \& } \\
\text { shoes }\end{array}$ & $\mathrm{KS}, \mathrm{MN}$ & KS & $\begin{array}{c}\text { Musical } \\
\text { instruments }\end{array}$ & All & All \\
\hline $\begin{array}{l}\text { Leather } \\
\text { products }\end{array}$ & IA, KS, MN & $\mathrm{MN}, \mathrm{KS}$ & $\begin{array}{l}\text { Steam } \\
\text { engines }\end{array}$ & IA, KS, MN & $\mathrm{MN}$ \\
\hline $\begin{array}{l}\text { Miscellaneous } \\
\text { clothing }\end{array}$ & All but $\mathrm{OH}$ & All but $\mathrm{OH}$ & $\begin{array}{c}\text { Iron } \\
\text { founding }\end{array}$ & $\begin{array}{l}\text { IA, KS, } \\
\text { MI, MN }\end{array}$ & $\mathrm{MN}, \mathrm{KS}$ \\
\hline $\begin{array}{l}\text { Printing \& } \\
\text { publishing }\end{array}$ & $\begin{array}{c}\text { IA, IL, } \\
\text { KS, MI, MN }\end{array}$ & $\mathrm{MN}, \mathrm{KS}$ & $\begin{array}{l}\text { Bar \& Rolled } \\
\text { iron }\end{array}$ & All & $\begin{array}{l}\text { IA, IL, KS, } \\
\text { MI, MN, WI }\end{array}$ \\
\hline $\begin{array}{l}\text { Soap \& } \\
\text { candles }\end{array}$ & $\mathrm{IA}, \mathrm{KS}, \mathrm{MN}$ & $\mathrm{MN}, \mathrm{KS}$ & $\begin{array}{l}\text { Pig } \\
\text { iron }\end{array}$ & All & $\begin{array}{c}\text { IA, IL, } \\
\text { KS, MN, WI }\end{array}$ \\
\hline
\end{tabular}

Notes: "All" consists of all the following states: Illinois, Indiana, Iowa, Kansas, Michigan, Minnesota, Missouri, Ohio, and Wisconsin. "IL" is Illinois, "IN" is Indiana, "IA" is Iowa, "KS" is Kansas, "MI" is Michigan, "MN" is Minnesota, "MO" is Missouri, "OH" is Ohio, "WI" is Wisconsin.

Table 7

Estimated Regional Production Breakdown Between Agriculture and Manufactures

\begin{tabular}{ccc}
\hline $\begin{array}{c}\text { Region and } \\
\text { product }\end{array}$ & $\begin{array}{c}\text { 1850 Share, } \\
\text { Percent }\end{array}$ & $\begin{array}{c}\text { 1860 Share, } \\
\text { Percent }\end{array}$ \\
\hline $\begin{array}{c}\text { Midwest } \\
\text { mfg }\end{array}$ & 20.4 & 18.8 \\
$\begin{array}{c}\text { Midwest } \\
\text { agr }\end{array}$ & 79.6 & 81.2 \\
$\begin{array}{c}\text { Northeast } \\
\text { mfg }\end{array}$ & 60.3 & 66.2 \\
$\begin{array}{c}\text { Northeast } \\
\text { agr }\end{array}$ & 39.7 & 33.8 \\
\hline
\end{tabular}

Source: The 1860 census. 